\title{
DERIVATIVE IMMUNITY: AN UNJUSTIFIABLE BAR TO SECTION 1983 ACTIONS
}

Section $1983^{1}$ provides a federal remedy for certain violations of constitutionally protected rights. To state a cause of action under section 1983, a complaint must allege that a "person" deprived the complainant of a constitutionally protected right, and that that person acted "under color" of state law. ${ }^{2}$ Purely private wrongful conduct is not subject to action under section 1983, although that provision does apply to private action that is related to state action of some kind. ${ }^{3}$ In United States $v$. Price, ${ }^{4}$ the Supreme Court left no doubt about the liability under section 1983 of private persons who conspire with state officials to deprive another person of his constitutional rights. Writing for a unanimous Court, Mr. Justice Fortas stated that

[p]rivate persons, jointly engaged with state officials in the prohibited action, are acting "under color" of law for purposes of the statute. To act "under color" of law does not require that the accused be an

THE FOLLOWING CITATIONS WILL BE USED IN THIS COMMENT:

C. Wright \& A. Miller, Federal. Practice and Procedure (1969) thereinafter cited as C. WRIGHT \& A. MILLER];

Schnapper, Civil Rights Litigation After Monell, 79 CoLuM. L. REv. 213 (1979) [hereinafter cited as Schnapper];

Developments in the Law—Section 1983 and Federalism, 90 HARV. L. REv. 1133 (1977) (hereinafter cited as Developments in the Law];

Note, "Vicarious Immunity" of Private Persons in Section 1983 Actions: "An Unexanined Assumption," 28 CASE W.L. Rev. 1014 (1978) [hereinafter cited as "Vicarious Immunity"].

I. 42 U.S.C. § 1983 (1976) (originally enacted as Civil Rights Act of 1871, ch. 22, § 1, 17 Stat. 13).

2. Section 1983 provides:

Every person who, under color of any statute, ordinance, regulation, custoin, or usage, of any State or Territory, subjects, or causes to be subjected, any citizen of the United States or other person within the jurisdiction thereof to the deprivation of any rights, privileges, or innnunities secured by the Constitution and laws, shall be liable to the party injured in an action at law, suit in equity, or other proper proceeding for redress.

3. Constitutional standards are apphied to private action when the government supports it or when private defendants "have assumed government powers or functions even without fornal government involvement." Note, State Action: Theories for Applying Constitutional Restrictions to Private Activity, 74 Colum. L. Rev. 656, 659 (1974). The scope of this Coinment is limited to cases in which the state action requirement of section 1983 is satisfied by a conspiraey between private parties and state officials. It will not examine those cases in which the private individual has assumed some governmental function, nor will it consider private conspiracies reached under 42 U.S.C. § 1985(c) (1976), which do not require state action. In the seminal case of Griffin v. Breckenridge, 403 U.S. 88 (1971), the Supreme Court held that "there must be some racial, or perhaps otherwise class-based, invidiously discriminatory animus behind the conspirators' action," id. at 102, before a cause of action can be established under section 1985(c).

4. 383 U.S. 787 (1966). 
officer of the State. It is enough that he is a willful participant in joint activity with the state or its agents. ${ }^{5}$

While the Supreme Court has made it clear that private persons who conspire with state officials acting beyond their authority are liable to suit under section $1983,{ }^{6}$ it has not taken a position on the liability of private individuals conspiring with public officials wlio are immune froin suit. ${ }^{7}$ Several of the courts of appeals, however, have adopted a doctrine of "derivative" or "vicarious" immunity in such cases. ${ }^{8}$ Simply stated, this doctrine posits that "[p]rivate persons cannot be held hable for conspiracy under [section 1983] if the other conspirators are state officials who are themselves immune to liability under the facts alleged."9 In other words, the immunity of the public official extends vicariously to the private party co-conspirator, thus insulatimg the private party from suit under section 1983. A plaintiff in such situations is completely deprived of his section 1983 action for damages.

A thorough analysis of the doctrine of derivative immunity deinonstrates numerous failings. The doctrine arose as an arguably unjusti-

5. Id. at 794 (footnote omitted). Although Price was a criminal prosecution involving 18 U.S.C. $\$ 242$ (1976), the Suprene Court had previously held that its construction of "under color of law" was identical for section 242 and section 1983. Monroe v. Pape, 365 U.S. 167, 185 (1961), overruled on other grounds, Monell v. Departinent of Social Servs., 436 U.S. 658, 663 (1978). Section 242 is the crimmal counterpart to section 1983. It provides that anyone who, under color of any law, deprives an inhabitant of any state, territory, or district of a constitutionally protected right may be subject to a fine of up to $\$ 1000$ or a prison sentence of up to one year, or both. If death results, as was the case in Price, any term of years may be imposed. In Adickes v. S.H. Kress \& Co., 398 U.S. 144 (1970), a section 1983 case, the Court held that "[a]ny notion that a private person is necessarily immune from hability under $\$ 1983$ because of the "under color of" requirements of the statute was put to rest by our holding in United States v. Price . . ." Id. at 174 n.44 (emphasis in original).

6. In Price, three local police officers allegedly conspired with 15 private defendants to murder three civil rights workers by releasing them from jail, transporting them to a deserted dirt road, and eventually killing them as they made their "escape." 383 U.S. at 790 . The police officers were apparently acting beyond their authority. Therefore, the 15 private defendants were indictable.

A section 1983 cause of action cannot be based on conspiracy alone. Lesser v. Braniff Airways, Inc., 518 F.2d 538, $540 \mathrm{n} .2$ (7th Cir. 1975). For instance, section 1983 does not provide a cause of action for "conspiracy to deny due process." Jennings v. Nester, 217 F.2d 153, 154 (7th Cir. 1954). "[A]ctual denial of due process [is required] before a cause arises." Id. The conspiracy issue, which this Comment addresses, only serves to satisfy the under color of state law requirement of section 1983. Although not dealt with specifically in this Comment, a deprivation of a right, privilege, or immunity protected by the Constitution is also necessary before a cause of action under section 1983 will arise. 42 U.S.C. $\$ 1983$ (1976).

7. The facts in Stump v. Sparkman, 435 U.S. 349 (1978), did bring this issue before the Court. Because it was not the issue raised or presented on appeal, however, the Supreme Court refused to decide it, although the Court did note the conflicting positions among the circuits. $I d$. at 364 n.13.

8. See notes $24-25$ infra and accompanying text.

9. Skyes v. California, 497 F.2d 197, 202 (9th Cir. 1974) (citations onitted). 
fied extension of the personal and municipal immunities developed by the Supreme Court to insulate certain defendants in section 1983 actions. Moreover, many courts inay apply the doctrine because they are unable to differentiate between the concepts of "state action" and "immunity." Fimally, the application of the doctrine is arbitrary because mere fortuity determines whether a private defendant will reap the benefits of this defense. The critical inquiry under the doctrine is whether the constitutional deprivation involved the action of an immune public official; the actions of the private party defendant play no part in triggering the defense.

This Comment will argue that a general doctrine of derivative immunity (also called "vicarious" or "per se" immunity) is unjustifiable. Initially, the Comment will discuss the development of the doctrine and its current status in the federal courts. Second, it will present the trends and standards over the past twenty years for section 1983 governmental immunities. The doctrine of derivative immunity will be evaluated against this backdrop and the arguinents agamst the doctrine will be developed. Special attention will be paid to a proposal for avoiding the derivative immunity issue suggested by the Court of Appeals for the Seventh Circuit in the recent case of Sparkman v. McFarlin. ${ }^{10}$ Next, this Comment will evaluate the First and Fifth Circuits' rejection of the doctrine and their standard of liability under section 1983. Fimally, it will propose an alternative that would establish a sliding scale of hability for private defendants, depending upon whether they acted with, in reliance on, or in obedience to public officials. A variable standard, which attaches liability to the extent of the private party's concerted action with public officials, may accommodate both the intent of section 1983 and the standards of tort liability better than the present doctrine of derivative immunity.

\section{The Development of Derivative Immunity}

The doctrine of derivative immunity was first enunciated in 1965 by the Court of Appeals for the Ninth Circuit in Haldane v. Chagnon. ${ }^{11}$ The plaintiff in Haldane had been ordered by the judge in a prior divorce proceeding to undergo a psychiatric examination. ${ }^{12}$ It was subsequently determined that the plaintiff's mental health did not require treatment under hospital confinement. ${ }^{13}$ In a suit for damages under section 1983, the plamtiff alleged a conspiracy to deprive him of several

10. 601 F.2d 261 (7th Cir. 1979) (per curiam) (en banc).

11. 345 F.2d 601 (9th Cir. 1965).

12. Id. at 602 .

13. Id. at 602 n.2. 
constitutional rights. Named as defendants were the trial court judge, the judge who had signed the order for the mental exammation, and two attorneys and a bailiff who had been involved in filing the petition for the examination. ${ }^{14}$ The district court dismissed the case and the plaintiff appealed to the Ninth Circuit. There the court had no trouble finding the defendant judges and bailiff immune from section 1983 as government officials. ${ }^{15}$ Moreover, the court ruled that the defendant attorneys could not be liable either:

The attorneys were not State officers, and they did not act in conspiracy with a State officer against whom appellant could state a valid claim. It follows that they did not and could not, commit the alleged wrongful acts "under color of state law or authority"; hence, they are not subject to liability under the Civil Rights Act. ${ }^{16}$

By holding that private parties are liable only if they act in conspiracy with a state official "against whom [the aggrieved party] could state a valid claim," the court extended the inmunity of state officials to cover private parties. The case neither elaborated nor justified this special status of private parties, ${ }^{17}$ and the language of section 1983 does not suggest that it should exist.

Althougl the otler courts of appeals did not adopt the doctrine of derivative immunity immediately, ${ }^{18}$ the Third, ${ }^{19}$ Fifth, ${ }^{20}$ Sixth, ${ }^{21}$ and Seventh $^{22}$ Circuits adopted it between 1970 and 1978. None of the circuits adopting the doctrine gave it a reasoned opinion; instead, each

14. Id. at 602 .

15. Id. at 604.

16. Id. at $604-05$ (emphasis added).

17. As support for its position, the court cited the following decisions: Skolnick v. Spolar, 317 F.2d 857, 859 (7th Cir. 1963); Skolnick v. Martin, 317 F.2d 855, 857 (7th Cir. 1963); Bottone v. Lindsley, 170 F.2d 705, 706 (10th Cir. 1948), cert. denied, 336 U.S. 944 (1949); Swift v. Fourth Nat'l Bank, 205 F. Supp. 563, 566 (M.D. Ga. 1962). See Haldane v. Chagnon, 345 F.2d at 605. These cases do not deal with conspiracies between private parties and state officials. The allegations of constitutional deprivation in these cases grew out of private litigation in state courts between the plaintiffs and defendants. The only involvement of the state was to provide a forum for the private litigation from which the alleged deprivations emerged. If anything, these cases stand only for the proposition that private attorneys, acting alone, do not act under color of state law.

18. Soon after Haldane, three district courts adopted the doctrine of derivative iminunity. Sce Stambler v. Dillon, 302 F. Supp. 1250, 1255 (S.D.N.Y. 1969); Jemzura v. Belden, 281 F. Supp. 200, 206 (N.D.N.Y. 1968); Shakespeare v. Wilson, 40 F.R.D. 500, 505 (S.D. Cal. 1966). See generally "Vicarious Immunity" 1030-31.

19. Waits v. McGowan, 516 F.2d 203, 205 (3d Cir. 1975).

20. Guedry v. Ford, 431 F.2d 660, 664 (5th Cir. 1970). The Fifth Circuit has recently reversed its position on derivative immnunity. See Sparks v. Duval County Ranch Co., 604 F.2d 976, 978 (5th Cir. 1979) (en banc), cert. denied, 100 S. Ct. 1339 (1980). See text accompanying notes 208-14 infra.

21. Kurz v. Michigan, 548 F.2d 172, 175 (6th Cir.), cert. denied, 434 U.S. 972 (1977).

22. Hansen v. Ahlgrimm, 520 F.2d 768, 770-71 (7th Cir. 1975). The Seventh Circuit's current position on derivative immunity is unclear. See Sparkman v. McFarlin, 601 F.2d 261 (7th Cir. 1979) (per curiain) (en banc). See notes 159-65 infra and accompanying text. 
court merely recited the doctrine as precedent with little further explanation. ${ }^{23}$ Thus, precedent for the doctrine grew, and continues to grow, without its ever having been justified fully by a circuit court decision.

The doctrine of derivative immunity is currently applied in three circuits, ${ }^{24}$ as well as four district courts outside those circuits. ${ }^{25}$ Only the First Circuit has consistently rejected the concept. ${ }^{26}$ The Fifth ${ }^{27}$ and Tenth ${ }^{28}$ Circuits recently rejected the doctrine, however, and a recent case in the Seventh Circuit indicates that the doctrine's validity is uncertain in that jurisdiction. ${ }^{29}$

It is obvious that the doctrine of derivative immunity is undergoing a much overdue evaluation. The doctrine was developed by the Ninth Circuit at a time when the Suprenie Court was enunciating the personal and inunicipal immunities to section 1983 actions. ${ }^{30}$ At that time several circuit courts simply went a step further by extending the

23. E.g., Kurz v. Michigan, 548 F.2d at 175; Hansen v. Ahlgrimm, 520 F.2d at 770-71; Waits v. McGowan, 516 F.2d at 205; Guedry v. Ford, 431 F.2d at 664.

24. The three circuits are the Ninth (Briley v. California, 564 F.2d 849, 858 (9th Cir. 1977)), the Sixth (Kurz v. Michigan, 548 F.2d at 175), and the Third (Waits v. McGowan, 516 F.2d at 205). In Jennings v. Shuman, 567 F.2d 1213, 1220 (3d Cir. 1977), however, the Third Circuit held that a private citizen can be hable under section 1983 if he conspires with a state official, although the court did not explicitly consider whether he would be liable if the state official were immune.

25. Gary v. Spires, 473 F. Supp. 878, 884 (D.S.C. 1979); Weiss v. Willow Tree Civic Ass'n, 467 F. Supp. 803, 811 n.21 (S.D.N.Y. 1979); Kane v. Graubard, 442 F. Supp. 733, 735 (S.D.N.Y. 1977); Dennis v. Hem, 413 F. Supp. 1137, 1141 (D.S.C. 1976); Harley v. Oliver, 404 F. Supp. 450, 455-56 (W.D. Ark. 1975); Jemzura v. Belden, 281 F. Supp. 200, 206 (N.D.N.Y. 1968).

26. Downs v. Sawtelle, 574 F.2d 1, 15 (1st Cir.), cert. denied, 439 U.S. 910 (1978); Slotnick v. Staviskey, 560 F.2d 31, 32 (1st Cir.), cert. denied, 434 U.S. 1077 (1977); Kermit Constr. Corp. v. Banco Credito Y Ahorro Ponceno, 547 F.2d 1, 3 (1st Cir. 1976). See notes 199-207 infra and accompanying text.

27. In Sparks v. Duval County Ranch Co., 604 F.2d 976, 978 (5th Cir. 1979) (en banc), cert. denied, 100 S. Ct. 139 (1980), the Fifth Circuit, sitting en banc, overruled the doctrine of derivative immunity, which had been well established in the circuit by the following line of cases: Perez $v$. Borchers, 567 F.2d 285, 287 (5th Cir.) (per curiam), cert. denied, 439 U.S. 831 (1978); Humble v. Foreman, 563 F.2d 780, 781 (5th Cir. 1977) (en banc); Hill v. McClellan, 490 F.2d 859, 860 (5th Cir. 1974); Guedry v. Ford, 431 F.2d at 664. See notes 209-14 infra and accompanying text.

28. Norton v. Liddel, No. 78-1712, slip op. at 7-8 (10th Cir. Mar. 6, 1980).

29. Sparkman v. McFarlin, 601 F.2d 261 (7th Cir. 1979) (per curiam) (en banc). See notes 159-65 infra and accompanying text.

To date, the Second, Fourth, and Eighth Circuits have not directly addressed the derivative immunity doctrine. Although the Second Circuit has not expressly taken a position, the opinion in Fine v. City of New York, 529 F.2d 70 (2d Cir. 1975), seems to indicate that it would not uphold the doctrine. In Fine, a private attorney was held to be liable to suit under section 1983 even though other attorneys joined as defendants in the suit wcre found to be immune. Id. at 73 . 74. The court did not mention the possibility of derivative immunity, but instead stressed the Supreme Court's holding in United States v. Price, 383 U.S. 787 (1966). See 529 F.2d at 73-75.

Section 1983 has no apphication in the District of Columbia Circuit. The Supreme Court has deternined that the District of Columbia is not a "state or territory" within the meaning of section 1983. District of Columbia v. Carter, 409 U.S. $418,432-33$ (1973).

30. See notes $31-97$ infra and accompanying text. 
immunities already given various governmental entities and officials to private parties actimg in concert with the immune officials. The critical mquiry, however, should be whether the justifications and constitutional standards for granting governmental immunity to section 1983 actions are applicable to private persons. If section 1983 imununities are to be extended derivatively to private parties, this question must be answered affirmatively.

\section{Governmental ImMunities Under Section 1983: Municipal AND PeRsonal}

Section 1983 renders every person who acts under color of state law to deprive another of a constitutionally protected right hable to the injured party in an action at law, equity, or other proceeding for redress. ${ }^{31}$ The language of the statute speaks im terms of strict liability without provision for viable defenses. ${ }^{32}$ During the late nineteenth century, however, the federal courts severely restricted the scope of the statute by narrowly interpreting both the constitutional rights protected by the statute and the ineaning of "under color" of state law. ${ }^{33}$

Until the Supreme Court's decision im Monroe v. Pape ${ }^{34}$ in 1961, the statute was rarely invoked. ${ }^{35}$ In Monroe the Court held applicable to section 1983 the broad interpretation it had earlier given to "under color of law" in 42 U.S.C. $\S 242,{ }^{36}$ the criminal counterpart to section 1983. ${ }^{37}$ The Court's subsequent expansive reading of both the due process and equal protection clauses to encompass many constitution-

31. See note 2 supra.

32. See Imbler v. Pachtman, 424 U.S. 409, 417 (1976); Pierson v. Ray, 386 U.S. 547, 559 (1967) (Douglas, J., dissenting). See note 207 infra.

33. Developments in the Law 1191. See generally id. 1156-61; "Vicarious Immunity" 1016-19.

34. 365 U.S. 167 (1961), overruled in part, Monell v. Department of Social Servs., 436 U.S. $658,663,701$ (1978).

35. See Developments in the Law 1161. Between 1871 and 1920, only 21 cases were brought under section 1983. Comment, The Civil Rights Act: Emergence of an Adequate Federal Civil Remedy?, 26 IND. L.J. 361, 363 (1951). During this same period, only 15 Supreme Court cases involved section 1983. "Vicarious Immunity" 1019 n.33. "As late as 1953, the statute was still relatively ineffective." Developments in the Law 1161 n.139. See generally Note, The Proper Scope of the Civil Rights Act, 66 HARv. L. REv. 1285 (1953).

36. 42 U.S.C. \$ 242 (1976). See Screws v. United States, 325 U.S. 91,111 (1945) ("under 'color' of law means under 'pretense' of law"); United States v. Classic, 313 U.S. 299, 326 (1941) ("Misuse of power, possessed by virtue of state law and made possible only because the wrongdoer is clothed with the authority of state law, is action taken 'under color of' state law'). See note 5 supra.

37. Monroe v. Pape, 365 U.S. at 185 ("Under color of law" means the same thing in section 1983 as it does in section 242). "In cases under $\$ 1983$, 'under color' of law has consistently been treated as the same thing as the 'state action' required under the Fourteenth Amendment." United States v. Price, 383 U.S. at 794 n.7. 
ally protected rights ${ }^{38}$ has caused the number of section 1983 suits to increase dramatically in recent years. ${ }^{39}$ In the last two decades, however, the federal judiciary has shifted its attention away from the problems of protecting private rights and finding the requisite state action and toward the other components of the section 1983 prima facie case. ${ }^{40}$ The courts have narrowed the range of parties that are potentially hable under section 1983 by restricting the definition of the term "person" in the statute ${ }^{41}$ and by developing personal immunities for certain state officials. These limitations served as the setting for the development of the doctrine of derivative immunity. More important, they provide the benclimark by which the doctrine should be evaluated.

\section{A. Absolute and Qualified Immunity Under Section 1983.}

On its face, section 1983 "creates a species of tort habihity that . . . adınits of no immunities . . .."42 The Supreme Court has therefore provided a shield froin damages under the statute for state legislators, judges, and prosecutors, as long as they have acted within their official capacities. In Tenney v. Brandhove, ${ }^{43}$ the Supreme Court held that leg-

38. "Vicarious Immunity" 1020.

39. In fiscal 1960, fewer than 300 private civil rights cases (cases in which the United States was not a party) were commenced in federal district court, accounting for $0.5 \%$ of the total civil workload. 1960 AD. OFF. OF U.S. CourTs, DiRECTOR's ANN. REP. 232, table C 2. By 1972 that number had risen to approximately 8,800 and constituted $9.2 \%$ of the civil caseload. 1972 AD. OFF. OF U.S. CouRTS, DiRector's ANN. REP. 286-87, table C 2. In fiscal 1979 nearly 23,000 private civil rights actions were commenced in federal court, accounting for $14.7 \%$ of the civil caseload. 1979 AD. OFF. OF U.S. Courts, DiRector's ANN. REP., at A-14 to -15, table C 2. Prisoner petitions have been the biggest cause of this increase, with 3,300 and 11,200 claims being commenced in 1972 and 1979 respectively. 1972 ANN. REP., supra at 287, table C 2; 1979 ANN. REP. supra at A-15, table C 2 . One authority estimates that almost one-third of the nearly 57,000 private federal question cases filed in the federal district courts in 1976 were civil rights actions asserting constitutional claims against state and local officials. P. BATOR, P. MISHKIN, D. SHAPIRO \& H. Wechsler, Hart \& Wechsler's The Federal Courts and the Federal System 149 (2d ed. Supp. 1977).

40. Developments in the Law 1191. Modern federal courts have used three means to linit the scope of section 1983: "the restrictive definition of the type of 'person' suable under the statute; the development of state of mind requirements requisite to a finding of liability; and the creation of linits on the availability of effective relief once liability las been found." Id. This Coniment will discuss only the limitations on the type of person amenable to suit and the state of mind requirements as they relate to the doctrine of derivative immunity. While all three limitations have had an impact on the development of law under section 1983, the relief limitation is beyond the scope of this Comment.

41. In light of the Supreme Court's recent decision in Monell v. Department of Social Servs., 436 U.S. 658 (1978), this limitation has been relaxed, although the parameters of the Court's new position have yet to be defined. See notes 83-93 infra and accompanying text.

42. Imbler v. Pachtman, 424 U.S. 409, 417 (1976).

43. 341 U.S. 367 (1951). 
islative immunity was so firmly established at common law ${ }^{44}$ and in both the federa ${ }^{45}$ and state ${ }^{46}$ constitutions that Congress would have specifically provided for its abolition under section 1983 lad it so intended. 47 Tenney established that section 1983 was to be read "in harmony with general principles of tort immunities and defenses rather than in derogation of them."48 This rationale was adopted by lower courts to create an absolute immunity for judges under section 1983.49 The Supreme Court approved this extension in Pierson v. Ray ${ }^{50}$ and recently reaffirmed the principle of absolute immunity for state court judges in Stump v. Sparkman. ${ }^{51}$ In Imbler v. Pachtman, ${ }^{52}$ the Court provided state prosecutors absolute immunity for actions taken in connection with "initiating a prosecution and ... presenting the State's case." 53

The purpose of absolute immunity is to proniote spirited public service and to prevent fearful decisionmaking that would result if the attention of judges, legislators, and prosecutors were diverted away from public trust and toward personal liability. ${ }^{54}$ The Supreme Court has "jealously guarded the proteetion accorded judges, legislators and

44. Id. at 372-76. The policy rationale for legislative immunity was, and remains, to protect the heart of the democratic process.

In order to enable and encourage a representative of the public to discharge his public trust with firmness and success, it is indispensably necessary, that he should enjoy the fullest liberty of speech, and that he should be protected from the resentment of every one, however powerful, to whom the exercise of that hberty may occasion offence.

Id. at 373 (quoting II Works of JAMES WILSON 38 (J. Andrews ed. 1896)).

45. 34 I U.S. at 373; see U.S. CoNST. art. I, \$6, cl. 1 (speech or debate clause).

46. At the time Tenney was decided, 41 of 48 states had "specific provisions in their Constitutions protecting the privilege." 341 U.S. at 375 .

47. Id. at 376.

48. Imbler v. Pachtman, 424 U.S. 409, 418 (1976).

49. See, e.g., Bauers v. Heisel, 36 I F.2d 581, 584-85, 586-87, 591-92 (3d Cir. 1966) (en banc).

50. 386 U.S. 547, 554-55 (1967). The Court relied heavily on the common law immunity from damages liability accorded judges for acts committed within their judicial jurisdiction. Id. at 553-54 (citing Bradley v. Fisher, 80 U.S. (13 Wall.) 335 (1871)). This absolute immunity was founded on the fear that judges would be lounded by hitigation charging malice or corruption and that such a burden would contribute not to principled and fearless decisionmaking, but to imtimidation. The immunity applies even when the judge is accused of malicious action and corruption. 386 U.S. at 554. The extension of section 1983 absolute immunity to judges has been severely criticized. See, e.g., Pierson v. Ray, 386 U.S. 547, 558-59 (1967) (Douglas, J., dissenting); Developments in the Law 1200-04.

51. 435 U.S. 349 (1978). A state judge will be subject to liabihty only when he has acted in the "clear absence of all jurisdictions." Id. at 356-57 (quoting Bradley v. Fisher, 80 U.S. (13 Wall.) 335,351 (1871)).

52. 424 U.S. 409 (1976).

53. Id. at 431 . As for judicial immumity, the policy rationales for prosecutorial immunity are to avoid diverting the prosecutor's attention away from the public trust and toward personal liability and to facihtate efficient operation of the criminal justice process. Id. at 424-26.

54. See notes $44,50, \& 53$ supra. 
prosecutors"ss to date, but it has refused to grant absolute immunity to any other state officials. ${ }^{56}$ Instead, the Court has extended qualified immunity to section 1983 claims to a growing number of officials.

In Pierson v. Ray ${ }^{57}$ the Supreme Court recognized, for the first time, the doctrine of qualified immunity. ${ }^{58}$ Dealing with the section 1983 liability of policemen, the Court held that a police officer's common law defense of good faith in the case of false arrest would also apply to section 1983.59 The Court clarified its position in Scheuer $v$. Rhodes ${ }^{60}$ and Wood v. Strickland. ${ }^{61}$ In Scheuer, the Court weighed the coinpeting public policies instead of unquestioningly adopting the common law immunity, as was done in Pierson. Balancing the need to protect state executive conduct with the objectives of section 1983, the Court rejected the absolute iminunity granted to executive officers at cominon law and extended to them only a qualified immunity-a good faith defense. ${ }^{62}$

Scheuer evidenced the Supreme Court's unwillingness to extend absolute immunity. The Court was also reluctant to establish a hiberal standard for good faith under the qualified immunity defense. In Wood, the Court held that the good faith standard encompasses both a subjective and an objective element. An official entitled to assert the immunity will be subject to liability for damages under section 1983 "if he knew or reasonably should have known that the action he took within his sphere of official responsibility would violate the constitutional rights of the [plaintiff], or if he took the action with the malicious intention to cause a deprivation of constitutional rights . . .."63

55. Downs v. Sawtelle, 574 F.2d 1, 11 (1st Cir.), cert. denied, 439 U.S. 910 (1978).

56. Although the Supreme Court has not sanctioned additional absolute immunities, some lower courts, relying on the trio of absolutes, have extended such immunity to other officials. See Denman v. Leedy, 479 F.2d 1097, 1098 (6th Cir. 1973) (judicial clerks); Smith v. Rosenbaum, 460 F.2d 1019, 1020 (3d Cir. 1972) (judicial clerks); Lucarell v. McNair, 453 F.2d 836, 838 (6th Cir. 1972) (municipal referees and judicial officers) (dictum); Pennebaker v. Chamber, 437 F.2d 66, 67 (3d Cir. 1971) (justices of the peace); Allison v. California Adult Auth., 419 F.2d 822, 823 (9th Cir. 1969) (parole board members). But cf. McCray v. Maryland, 456 F.2d 1, 4-5 (4th Cir. 1972) (act of clerk purely ministerial and outside the protection afforded by the doctrine of judicial immunity).

57. 386 U.S. 547 (1967). Pierson was also the case in which the Court recognized the absolutc immunity of state judges. See text accompanying note 50 supra.

58. The term "qualified immunity" is misleading. While absolute immunity will serve to defeat an action from the outset, qualified immunity is a defense dependent upon the circumstances and motivations of the defendant's actions. See lmbler v. Pachtman, 424 U.S. 409, 419 n.13 (1976); Wood v. Strickland, 420 U.S. 308, 320-22 (1975); Scheuer v. Rhodes, 416 U.S. 232, 238-39 (1974).

59. Pierson v. Ray, 386 U.S. at 557.

60. 416 U.S. 232 (1974).

61. 420 U.S. 308 (1975).

62. 416 U.S. at 242-48; see "Vicarious Immunity" 1025.

63. 420 U.S. at 322. 
Since 1967 the Supreme Court has held that the good faith defense, in section 1983 actions, applies to policemen, ${ }^{64}$ governors, ${ }^{65}$ university presidents, ${ }^{66}$ officers and members of national guards, ${ }^{67}$ school board members, ${ }^{68}$ superintendents of mental hospitals, ${ }^{69}$ and prison officials. ${ }^{70}$ In addition, the courts of appeals have not hesitated to extend qualified immunity to a variety of other officials, including parole officers, ${ }^{71}$ jailers ${ }^{72}$ and state banking officials. ${ }^{73}$ Although the category of officials held to be immune under section 1983 has expanded, the trend has been to limit the scope of this immunity. The Supreme Court's approach to qualified immunity has been to examine the legislative intent of the statute, the immunity accorded at common law, and the policy considerations that support the concept of immunity before extending it to a section 1983 defendant. ${ }^{74}$ This analysis, lowever, was lacking in the developinent of the derivative immunity doctrine. In fact, these factors militate against extending immunity derivatively to private defendants in section 1983 actions. ${ }^{75}$

This discussion of qualified immunity has delineated the standards under which an extension of immunity is appropriate and lias illustrated the dwindling number of potential defendants for a section 1983 suit. Qualified immunity, however, does not appear to be an appropriate springboard for the extension of derivative immunity to private persons. Although the circuits adopting derivative immunity have not expressly so indicated, ${ }^{76}$ the doctrine can operate only when the private defendant conspired with a public official who is absolutely immune. Absolute immunity bars an action from the outset. While qualified immunity is a defense, its viability depends upon the circumstances and

64. Pierson v. Ray, 386 U.S. 547, 557 (1967).

65. Scheuer v. Rhodes, 416 U.S. 232, 242-43, 247-50 (1974).

66. Id.

67. Id.

68. Wood v. Strickland, 420 U.S. 308, 322 (1975).

69. O'Connor v. Donaldson, 422 U.S. 563, 576-77 (1975).

70. Procunier v. Navarette, 434 U.S. 555, 561-62 (1978).

71. Wolfel v. Sanborn, 555 F.2d 583, 591 (6th Cir. 1977).

72. Bryan v. Jones, 530 F.2d 1210, 1213-15 (5th Cir.), cert. denied, 429 U.S. 865 (1976).

73. Guzman v. Western State Bank, 540 F.2d 948, 951-52 (8th Cir. 1976).

74. See "Vicarious Immunity" 1024-26.

75. See notes 98-136 infra and accompanying text.

76. The First Circuit's opinion in Downs v. Sawtelle, 574 F.2d 1 (lst Cir.), cert. denied, 439 U.S. 910 (1978), contributes to the confusion on this point. In Downs, the public officials involved in the alleged conspiracy were subject to qualified, rather than absolute, immunity. The First Circuit, in maintaining its consistent position against derivative immunity, refused to extend immunity derivatively to the private defendants. 574 F.2d at 15 . Thus, the court was taking the opportunity to reject the doctrine in a case in which it could not arise anyway. 
motivations of the official's actions. ${ }^{77}$ If the official covered by qualified inmunity has participated in a conspiracy, his action cannot reasonably be characterized as being in good faith and he cannot claim inmunity. If the official has no nnmunity, then the private defendant with whom he conspired can have no derivative immunity. ${ }^{78}$ If the public official has acted in good faith, he cannot have been party to a conspiracy. The public official who is cloaked with absolute immunity, however, will maintain his immunity regardless of his lack of good faith or conspiratorial motive. ${ }^{79}$

\section{B. Municipal Liability Under Section 1983.}

While the Supreme Court gave section 1983 a shot in the arm in Monroe v. Pape 80 by construing the "under color of law" requirement broadly, the Court also, in the same case, severely limited the number of potential defendants. In Monroe, the Court held that cities and municipal corporations were not "persons" liable to suit under section 1983.81 This municipal immunity, combined with the expanding notion of official nnmunity and the eventual creation of derivative immu-

77. See note 58 supra.

78. Thus, as formulated, the doctrine of derivative immunity would never be triggered. The private defendant would have acted with a public official against whom the plaintiff could state a valid claim. See text accompanying note 16 supra.

79. For instance, the only constraint on a judge is that he must not act in a clear absence of jurisdiction. Lessman v. McCormick, 591 F.2d 605 (10th Cir. 1979), illustrates the operation of qualified immunity in a conspiracy setting. In that case, the plaintiff alleged that bank officials arranged to have her arrested for failure to pay a parking ticket. She was held at the police station after paying her fine and was not released until she talked to a bank officer. The court found that the bank officcr instilled fcar in the plaintiff so that she would give the bank a preferred position in relation to ler other creditors. Id. at 607 . The court upheld the sufficiency of the complaint against the policeman and the bank official. Although policemen are subject to qualified immunity, see text accompanying notes 57-59 supra, the court held that the police officer would be liable under section 1983 if he arrested plaintiff "for an improper purpose." 591 F.2d at 611. If the police officcr had conspircd with the bank official, he could not have acted in good faith and could not be immune. Thus the issue of derivative immunity for the bank official did not arise.

In Norton v. Liddel, No. 78-1712 (10th Cir. Mar. 6, 1980), the issue of derivative immunity did arise in the Tenth Circuit and the court rejected the concept, thus contributing to the recent trend against it. Inportantly, the court mamtamed its consistent distinction between absolute and qualified immunity. The private defendant in Norton was a local sherif who was alleged to have conspired with the district attorney. Under the official immunities developed by the Supreme Court, sce notes 42-73 supra and accompanying text, prosecutors are covered by absolute immunity while police officers only enjoy qualified immunity. Thus, the Norton court held that if the sheriff had actively conspired with the prosecutor he would be liable under section 1983 since he would have breached his duty of good faith required by the derivative immunity defense. Norton v. Liddel, No. 78-1712, slip op. at 7, 11. The prosecutor would not be liable regardless of his good faith or lack thereof due to the absolute nature of his iminunity.

80. 365 U.S. 167 (1961), overruled in part, Monell v. Department of Social Servs., 436 U.S. $658,663,701$ (1978).

81. 365 U.S. at 187. 
nity for private defendants, greatly diminished the usefulness of the section 1983 action. 82

The Supreme Court made a stark reversal in Monell v. Department of Social Services ${ }^{83}$ by expressly overruling Monroe $^{84}$ and its progeny ${ }^{85}$ insofar as they held local governments wholly immune from suit under section 1983. Relying solely upon legislative history, as it had done in Monroe, ${ }^{86}$ the Court held that a reexamination of the linstory of section 1 of the Civil Rights Act of 1871 (now codified in section 1983) compelled the conclusion that "Congress did intend nunicipalities and other local government umits to be mcluded among those persons to whom 1983 applies." 87 Although Monell might amehorate the plight of many justified plaimtiffs, the case nevertheless fails to spell out the exact requirements for municipal liability. ${ }^{88}$ Thus, the Court has left the ini-

82. The combined effect of these factors rendered section 1983 ineffective as a deterrent and led many commentators to call for a reappraisal of Monroe. See, e.g., Kates \& Kouba, Liability of Public Entities Under Section 1983 of the Civil Rights Act, 45 S. CAL. L. REv. 131, 134-36 (1972); McCormack, Federalism and Section 1983: Limitations on Judicial Enforcement of Constitutional Protections, Part I, 60 VA. L. Rev. 1, 6-10 (1974).

Between 1973 and 1976, in response to growing confusion among the lower federal courts, the Supreme Court attempted to delineate the parameters of Monroe. See City of Kenosha v. Bruno, 412 U.S. 507, 513 (1973) (a city is not a "person" for section 1983 purposes even if only equitable relief is sought); Moor v. County of Alaneda, 411 U.S. 693, 700-02 (1973) (counties, as subdivisions of the state, are immune from section 1983 suits). For a general discnssion of these cases, see Note, Civil Rights: Discarding Section 1983 Municipal Immunity-Is That Enough?, 30 U. FLA. L. REv. 979, 982-86 (1978).

83. 436 U.S. 658 (1978).

84. Id. at 663 .

85. See Sclinapper 264 ("Clearly Monell destroys the basis of . . . Moor").

86. See 365 U.S. at $187-92$.

87. 436 U.S. at 690 (emphasis in origmal) (footnote omitted). The Court, however, was quick to point out that "Congress did not intend inumicipalities to be held liable unless action pursuant to official inunicipal pohicy of some nature cansed a constitutional tort." Id. at 691 .

88. See Sclinapper 216; Note, The Emergence of Municipal Liability Under 42 U.S.C. \& 1983, 8 CAP. U.L. REV. 103, 110-13 (1978). Two major types of section 1983 cases make defining municipal liabihity very difficult. First, there are cases founded on some official policy, standard, or custom of local government. Monell itself is sucl a case, stemming from the written regulations of two city departments dealing with unaternity policy. 436 U.S. at 661 . The case contains several vague and differing descriptions of what is required for section 1983 liability: (a) "a policy statement, ordimance, regulation, or decision officially adopted and proinulted by [the inunicipality's] officers," $i d$. at 694, (b) an action or policy that lias "received formal approval through the body's official decisionmaking channels," $i d$. at 691 , or (c) an action or policy "inade by its law makers or by those whose edicts or acts may fairly be said to represent official policy," id. at 694 . See Schnapper 216.

Second, there are cases involving acts of one or more city employees that result in depriving another of a constitutional right. These cases have come to be known as "constitutional tort" cases. Note, supra, at 112 . The Court in Monell concluded that "a municipality cannot be lield hable solely because it employs a tortfeasor-or, in other words, a inumicipality cannot be lield liable under $\S 1983$ on a respondeat superior theory." 436 U.S. at 691 . The remaining problem is determining the additional elements, aside froun respondeat superior, needed to establislt unumipal liability in these cases. For a good discussion of this point, see Sclinapper 265-66 ("if state or 
tial resolution of the contours of mumicipal liability, like the question of derivative immunity for private persons, ${ }^{89}$ to the lower federal courts. 90

The overriding importance of Monell is found in the position that the Supreme Court has taken on the purpose and scope of section 1983. Monell evidences a trend away from prior judicial limitations on section 1983 actions and toward increased recovery under the statute. Writing for the majority, Mr. Justice Brennan stated that "there can be no doubt that [section 1983] was intended to provide a remedy, to be broadly construed, against all forms of official violation of federally protected rights."91 In addition, the Court declined the opportunity to extend official immumity to local government bodies. The brief cominents on immunity in Monell addressed limitation only, and not extension: "We express no views on the scope of any municipal immunity beyond holding that inunicipal bodies sued under $\S 1983$ cannot be entitled to an absolute immunity, lest our decision that such bodies are subject to suit under $\S 1983$ 'be drained of ineaning." "92

The importance of Monell extends beyond the limited circumstances of inunicipal liability and immunity. As one commentator has noted:

The practical importance of other decisions such as those providing absolute immunity for judges, prosecutors, and legislators, and qualified immunity for executive officials, turned on Monroe . . . . Thus, the foundation of many of these procedural and remedial rules was destroyed in June 1978 when the Supreme Court overruled Monroe in Monell v. Department of Social Services..$^{93}$

Clearly, the Court's new einphasis in Monell weakens the basis of the derivative immunity doctrine as well.

local law imposes tort liability on a government body according to the principles of respondeat superior, those principles should be applied under section 1988 in a section 1983 action"). Contra, Baskin v. Parker, 602 F.2d 1205, 1208 (5th Cir. 1979) (per curiain) ("state vicarious liability doctrines are inapplicable to $\S 1983$ suits"). Even when only respondeat superior can be shown in these "constitutional tort" cases, Monell does not say that the individual (employee) tortfeasor will be personally immune from suit. A cause of action will exist against him.

89. See note 7 supra and accompanying text.

90. Monell v. Departinent of Social Servs., 436 U.S. at 713-14.

91. Id. at 700-01.

92. Id. at 701 .

Recently, in Owen v. City of Independence, 100 S. Ct. 1398 (1980), the Supreme Court answered the the immumity question left open in Monell, loolding that in section 1983 suits for dam* ages, municipalities are not entitled to qualified immunity based on the good faith of their officials. In so holding, the Court applied the sane method of analysis that is discussed in this Comment. It examined the language of section 1983, the legislative intent of the statute, the inmunity accorded at coinmon law, and the policy considerations that support the concept of immunity. See text accompanying note 74 supra. The Conrt found that none of these considerations support the extension of qualified immunity to municipalities. Id. at 1415-16.

93. Schnapper 213-14 (footnotes ounitted). 
The judicial interpretation of governmental immunities under section 1983 reveals strong competing interests in the law. As the Court of Appeals for the Third Circuit has appraised:

On the one hand there is the public interest in vindicating individual rights sought to be protected by the Civil Rights Act. On the other hand, there exists a strong public policy in promoting spirited service by public servants, a goal thought to be placed in jeopardy by the threat of private damage suits for official actions. ${ }^{94}$

The Supreme Court has adopted the position that section $1983 \mathrm{immu}-$ nities must be "predicated upon a considered inquiry into the immunity historically accorded the relevant official at common law and the interests behind it."95 Nevertheless, the Supreme Court has not inquired into the liability of private parties who conspire with immune public officials, and the lower courts that have established the doctrine of derivative immunity have failed to seek historic justifications for their actions. ${ }^{96}$ In light of the Monell decision and its implications ${ }^{97}$ and the growth of qualified government immunities, the time is ripe for a reexamination in the federal courts of the doctrine of derivative immunity.

\section{The Per Se Rule of Derivative Immunity}

\section{A. Applying the Immunity Standards.}

As indicated previously, ${ }^{98}$ the Supreme Court has developed a three-fold analysis to determine whether and to what extent section 1983 immunity should be granted. The analysis requires an exammation of the legislative intent of section 1983, the immunity accorded at common law, and the policy considerations supporting that immunity.

The legislative history of section 1983 reveals no congressional consideration of the issue of private party immunity. ${ }^{99}$ In fact, the statute was aimed not at private persons, but rather at the inaction of state and local authorities in the face of the Ku Klux Klan's lawless and unbridled activities. ${ }^{100}$ At the time section 1983 was enacted, the coinInon law did not embody any principle to extend vicariously the immu-

94. Fidtler v. Rundle, 497 F.2d 794, 797 (3d Cir. 1974).

95. Imbler v. Pachtman, 424 U.S. 409, 421 (1976).

96. See notes 16-23 supra and accompanying text.

97. See text accompanying note 93 supra.

98. See note 74 supra and accompanying text.

99. "Vicarious Immunity" 1036.

100. See Monroe v. Pape, 365 U.S. at $175-76$ ("the renedy created was not a renedy against [the Klan] or its nembers but against those who representing a State in some capacity were unable or unwilling to enforce a state law") (emphasis in origmal). See generally "Vicarious Immunity" 1016-17. 
nity of officials to the actions of private persons. ${ }^{101}$ The only current precedent for the extension is the unreasoned opinion in Haldane and its progeny. ${ }^{102}$ It is important to note that Supreme Court decisions since Haldane that have held private persons liable under section 1983 have not inentioned applying official immunity to private parties. ${ }^{103}$ Thus, an analysis of both the legislative history of section 1983 and the common law does not support the derivative grant of immunity to private persons. If private parties are to be grantcd immunity, the justification must therefore be based on public policy.

The policy objective currently recognized by the Supreme Court to justify grantmg immunity to public officials - encouraging public servants to give spirited service free from the fear of damages liability 104 -is not applicable to private persons. As the Court of Appeals for the First Circuit has noted, "[p]rivate parties siniply are not confronted with the pressures of office, the often split-second decisionmaking or the constant threat of liability facmg police officers, governors and other public officials." 105 Private persons are, of course, free not to act at all. ${ }^{106}$ It inust be asked, however, wliether there are otlier policy considerations on which a doctrine of derivative immunity could be founded. There are several policy arguments that have at various times been forwarded as justifications for the doctrine of derivative immumity. ${ }^{107}$

1. Discouraging Frivolous Civil Rights Claims. One of the inost frequently articulated justifications for the doctrine of derivative int1nunity is the need to discourage frivolous civil rights claims. ${ }^{108}$ The natural implication of this argunient is that, in the absence of derivative immunity, any time a claimant alleges a conspiracy between private persons and immune officials, the issue inust be litigated under section 1983.109 Although many frivolous actions are screened out by the per

101. "Vicarious Immunity" 1036; see Sparkman v. McFarlin, 601 F.2d 261, 273 (7th Cir. 1979) (en banc) (Swygert, J., dissenting).

102. See notes 11-23 supra and accompanying text.

103. See, e.g., Adickes v. S.H. Kress \& Co., 398 U.S. 144 (1970); United States v. Price, 383 U.S. 787 (1966). See notes 149-50 infra and accompanying text.

104. See notes $44,50, \& 53$ supra.

105. Downs v. Sawtelle, 574 F.2d 1, 15 (1st Cir.), cert. denied, 439 U.S. 910 (1978); accord, Sparkman v. McFarlin, 601 F.2d at 273-74 (Swygert, J., dissenting).

106. Sparkman v. McFarlin, 601 F.2d at 274 (Swygert, J., dissenting).

107. These arguments are catalogued in Sparkman v. McFarlin, 601 F.2d at 267 (Sprecher, J., concurring).

108. See Sparks v. Duval County Ranch Co., 604 F.2d 976, 989 (5th Cir. 1979) (en banc) (Coleman and Ainsworth, JJ., dissenting), cert. denied, 100 S. Ct. 1339 (1980); Sparkman v. McFarlin, 601 F.2d at 267 (Sprecher, J., concurring).

109. Proponents of the doctrine of derivative immunity have asserted that in its absence, "any- 
se rule of derivative immunity, many worthy section 1983 claims may also be dismissed. ${ }^{110}$ The frivolous claims argument ignores the critical fact that section 1983 does not give rise to a cause of action merely because a conspiracy between a private person and a state official is alleged. First, there must be a deprivation of a constitutional right. As has been noted, "[t] he gist of the cause of action [under section 1983] is the deprivation . . . ."111 Second, the deprivation must be carried out under color of state law. The screening of frivolous claims can be accomplished by close scrutiny of the section 1983 requirements. Dismissing a claim for failure to allege the requisite deprivation of constitutional protections or state action is handled more properly under the Federal Rules of Civil Procedure than under a per se rule of vicarious immunity. ${ }^{112}$

\section{Preventing Federal Court Monitoring of State Court Proceed-} ings. Section 1983 cases discussing derivative immunity have often involved allegations of deprivations during the course of state court proceedings. ${ }^{113}$ Proponents of the doctrine of derivative immunity

one dissatisfied with the result of the litigation in state court can allege a 'conspiracy' sufficient to obtain federal court review of his claim." Sparks v. Duval County Ranch Co., 604 F.2d at 988 (Coleman and Ainsworth, JJ., dissenting).

110. In its recent rejection of the doctrine of derivative immunity, the Fifth Circuit noted:

We recognize that in doing so we cast away a tool for discouraging possible inischievous lawsuits that, by intention or effect, lharass judges for performing their offices. But this tool, like a hot flatiron, is too awkward for service as a cautery and works too nuch damage to surrounding structures for the small benefit it confers.

Id. at 983 .

111. Lesser v. Braniff Airways, Inc., 518 F.2d 538, 540 n.2. (7th Cir. 1975).

112. See Slotnick v. Staviskey, 560 F.2d 31, 33 n.1 (1st Cir. 1977), cert. denied, 434 U.S. 1077 (1978). See notes 166-69 infra and accoinpanying text. The recent case of Henzel v. Gerstem, 608 F.2d 655, 659 (5th Cir. 1979), illustrates that derivative imnunity is not necessary to screen frivolous claims agamst private persons. Henzel was decided after the Fifth Circuit rejected derivative immunity in Sparks. See notes 208-14 infra and accompanying text. The court rejected the theory that summary judgment could be granted to the private defendants on the basis of derivative immunity, but instead held that summary judgment would be appropriate because the allegations of conspiracy were conclusory and wholly unsupported. As Henzel suggests, when derivative imnunity is rejected, review of the pleadings in conspiracy cases will take on greater importance in screening frivolous claims.

113. E.g., Sparks v. Duval County Ranch Co., 604 F.2d at 978 (state court judge, alleged to have conspired with defendants, entered injunction prohibiting plaintiffs fronı producing oil); Sparkman v. McFarlin, 601 F.2d at 261 (state court judge, alleged to have conspired with defendants, signed petition for sterilization of plaintiff); Perez v. Borchers, 567 F.2d 285, 286-87 (5th Cir.) (per curiani) (tax collector alleged conspiracy and unlawful criminal prosecution at exainination hearing in which justice of peace ruled that he should be bound over to the grand jury in connection with missing sales tax receipts), cert. denied, 439 U.S. 831 (1978), overruled, Sparks v. Duval County Ranch Co., 604 F.2d 976, 978, 983 (5th Cir. 1979) (en banc), cert. denied, 100 S. Ct. 1339 (1980); Hill v. McClellan, 490 F.2d 859, 860 (5th Cir. 1974) (per curiam) (state prisoner alleged that judge, attorney, and ex-wife conspired to have default judginent in divorce, child custody, and property settlement action in state court entered against him while he was incarcerated and 
charge that, even though immune state court judges cannot be named defendants, allegations of conspiracy are an attempt to make them "personally answerable in federal court to private litigants for their state judicial . . . acts,"114 and "to obtain a review and a retrial of the State Court proceedings." 115 Furthermore, it is argued that the federal courts, under the guise of enforcing civil rights, might monitor the state courts and "furmsh a remedy for each losing party in every state court proceeding." 116 If section 1983 suits in federal court were to have these effects, the relationship between state and federal courts would be dramatically altered. These consequences, however, do not result from a section 1983 suit.

The only question raised by an alleged section 1983 conspiracy involving state court judges is whether the judge conspired with a private party to deprive the plaintiff of his constitutionally protected rights. Moreover, the federal courts have original jurisdiction, not appellate jurisdiction, in a civil rights complaint. The 1983 suit is neither a retrial of the state court proceedings nor a review of that court's legal theories. The state court proceeding inerely provides the factual setting for the alleged conspiracy. It is true that if a section 1983 conspiracy is found to exist, injunctive rehef dissolving the state court's decision may be granted. If no conspiracy is found to exist, however, the inquiry in federal court will end. Federal adjudication of an action alleging a section 1983 conspiracy between a private person and an immune state judge does not create a sovereignty crisis between the state and federal systems.

3. Promoting the Cooperation of Private Persons with State Officials. Proponents of the doctrine clain that without derivative immumity, the fear of liability under section 1983 would deter private persons from reporting crimes or cooperating with state officials. They note that

private persons who are victims of, or witnesses to a crime should not be discouraged from reporting the crime or froin following the advice of a prosecuting attorney as to whether to lodge a fornal complaint against, or to appear as a witness against, the perpetrator.

unable to appear in court); Haldane v. Chagnon, 345 F.2d 601, 602 (9th Cir. 1965) (party to divorce action ordered by state court judge to undergo mental health examination).

114. Sparks v. Duval County Ranch Co., 604 F.2d at 986 (Coleman and Ainsworth, JJ., dissenting) (emphasis in original).

115. Id. at 988 (Coleman and Ainsworth, JJ., dissenting) (quoting French v. Corrigan, 432 F.2d 1211, 1213 (7th Cir. 1970)).

116. Sparkman v. McFarlin, 601 F.2d at 267 (Sprecher, J., concurring). It should be recognized that this argument is a particularized form of the frivolous claims theory. See notes 108-12 supra and accompanying text. 
Similarly, in civil matters, private persons should not be discouraged from or penalized for seeking the aid or judicial approval of a court before embarking upon activities of ambiguous legality. ${ }^{117}$

This argument overlooks the requirements of section 1983 liability. It suggests that merely seeking the advice of a prosecutor or a court or testifying as a witness will subject private mdividuals to section 1983 hability. Reporting a crime or cooperating with state officials does not by itself violate the statute, however. A section 1983 plaintiff inust allege and prove a conspiracy to deprive him of a constitutional right. The unilateral act of filing a complaint or testifying at trial is simply not within the scope of the statute.

4. Preventing a Time-Consuming Collateral Attack Against Immune State Actors. Although an immune state official cannot be named as a party defendant in a section 1983 conspiracy, it has been asserted that allowing the alleged private co-conspirator to be sued would subject the public official to a collateral attack on his reputation and integrity. ${ }^{18}$ This attack would raise in the state actor an "apprehension of personal consequences to himself," 119 thereby frustrating the rationale for cloaking the state official with immunity. In addition to threatening the official's reputation, discovery and time-consuming appearances as a witness would keep the official from performing his public duties. ${ }^{120}$

The section 1983 immumity enjoyed by judges, prosecutors, and certain other state officials exists not for the personal benefit of the state actor, ${ }^{121}$ but to promote spirited public service. ${ }^{122}$ Immunity is a harsh rule and one "laden with potential for unredressed wrong." 123 Because it is an exception to the strict liability rule of section 1983, it has been limited to particular classes of officials and protects them only from liability for damages. It is true that requiring officials to testify at a conspiracy trial allows collateral attack of their integrity. This injury is comparatively insigmificant, however, when the alternative is to confer immunity on a private party who has joincd with an official to deprive

117. Sparkman v. McFarlin, 601 F.2d at 267 (Sprecher, J., concurring).

118. See Sparks v. Duval County Ranch Co., 604 F.2d at 984-86 (Coleman and Ainsworth, JJ., dissenting).

119. Id. at 984 (quoting Stump v. Sparkman, 435 U.S. 349,355 (1978)).

120. See Sparkman v. McFarlin, 601 F.2d at 267 (Sprecher, J., concurring).

121. See Sparks v. Duval County Ranch Co., 604 F.2d at 979 ("the absolute immunity that judges enjoy exists for the benefit of the judicial system and of the public, not for that of the judge").

122. See notes $44,50 \& 53$ supra.

123. Sparks v. Duval County Ranch Co., 604 F.2d at 980. 
another person of a constitutional right. ${ }^{124}$ Furthermore, even im jurisdictions that apply derivative immumity, an attack on an official's reputation may be made. State judges, for instance, are amenable to process in many situations. ${ }^{125}$ In addition, there are many other means of attacking an official's reputation. ${ }^{126}$ Thus, derivative immunity, if its purpose is to protect official reputations, is underinclusive.

The time and effort expended by public officials testifying at conspiracy trials is an unresolved empirical question. With respect to state judges, the Court of Appeals for the Fifth Circuit has held that this obligation is comparatively insignificant. ${ }^{127}$ At the very least, the burden should be on the proponents of derivative immunity to establish their claim of duty interference empirically before it is endorsed as a justification for the doctrine. Any shight imconvenience and embarrassment for the state official is surely "less important than . . . brimging conspirators to book." 128

\section{Preventing Unfairness in Holding One Conspirator Immune and} Another Liable. It has been suggested that it "seems manifestly unfair" that the state's expert should be immunized from attack under section 1983 while the untutored lay person is left vulnerable to a costly attack for participating in the same activity as the state official. ${ }^{129}$ Although soine form of protection is legitimate for a private party who, in good faith, relies on or simply obeys a state official, ${ }^{130}$ there is nothing novel in holding co-conspirators liable even though a fellow conspirator is immune. ${ }^{131}$ As the Fifth Circuit has recently asserted, "[a]t least two

124. See id. Even if suits against private persons were used as a techinque to harass the iminuue officials, a summary judgment proceeding under rule 56 of the Federal Rules of Civil Procedure, with liberal use of affidavits and depositions, would be preferable to the dismissal of all similar section 1983 suits under the theory of derivative immunity. See also Bristow, $\$ 1983: \mathrm{An}$ Analysis and Suggested Approach, 29 ARK. L. REv. 255, 326-27 (1975).

125. State judges are not immune from equitable relief. Sparks v. Duval County Ranch Co., 604 F.2d at 980; see Wood v. Strickland, 420 U.S. 308, 315 n.6 (1975) ("immunity from damages does not ordinarily bar equitable relief as well"); United Steelworkers v. Bishop, 598 F.2d 408, 413 (5th Cir. 1979) (leaving open possibility that judge "may be the object of equitable relief in proper cases"). Nor does immunity exist for judges under the criminal law. A state judge is also amenable to process when he is a witness to an incideut giving rise to a lawsuit. Sparks v. Duval County Ranch Co., 604 F.2d at 981.

126. Because of the current state of defamation law and the public figure status of state court judges, the inedia provide useful forums for attaeking these judges' integrity and reputation.

127. Sparks v. Duval County Ranch Co., 604 F.2d at 980 . Contra, id. at 989 (Coleman and Ainswortli, JJ., dissenting).

128. Sparkman v. McFarlin, 601 F.2d at 274 n.9 (Swygert, J., dissenting) (quoting Slotnick v. Staviskey, 560 F.2d 31, 33 n.1 (1st Cir. 1977), cert. denied, 434 U.S. 1077 (1978)).

129. Sparkman v. McFarlin, 601 F.2d at 267 (Sprecher, J., concurring).

130. See notes 221-31 infra and accompanying text.

131. See, e.g., Ewald v. Lane, 104 F.2d 222, 224 (D.C. Cir.) (wife allowed to proceed against 
persons must join in an unlawful enterprise to constitute it a conspiracy. . . But both need not be prosecuted, or prosecutable. One may die, may escape, or obtain pardon; but the other remains guilty.' "132

In section 1983 cases, there can be little objection to holding a person liable for his acts, independent of the treatment of those who acted with him. The Supreme Court has commanded that the statute "be read against the background of tort liability that makes a man responsible for the natural consequences of his actions." 133 The doctrine of derivative immunity nevertheless offers an "actual incentive to corruption ... . with its promise of civil immunity to those who succeed in involving a [state official's] powers in their nefarious schemes . . ."134 This result is clearly at odds with the mandate in section 1983 to enforce the guarantees of the fourteenth amendment. ${ }^{135}$

The foregoing diseussion deinonstrates that the policy arguments forwarded by the proponents of derivative immunity are unconvincing. From its very beginning in Haldane, the doctrine developed without a careful inquiry into the underlying issues and policies. ${ }^{136}$ Stare decisis, not exactimg legal analysis, may be the best explanation for current support of the doctrine. A complete evaluation of the doctrine of derivative immunity reveals several additional factors that reflect adversely upon its soundness.

\section{B. State Action and Immunity-A Confusion of Concepts.}

Under the doctrine of derivative immunity, a plaintiff bringing a section 1983 action agamst a private party must be able to state a valid claim agamst the public official with whom the private party is alleged to have conspired; ${ }^{137}$ if the official is immune, the requirement cannot

two co-conspirators even though a third, her husband, was dismissed because of interspousal immunity), cert. denied, 308 U.S. 568 (1939); Farnsworth v. Zerbst, 98 F.2d 541, 544 (5th Cir. 1938) (conspiracy conviction affirmed even though co-conspirator enjoyed diplomatic immunity).

132. Sparks v. Duval County Ranch Co., 604 F.2d at 981 (quoting Farnsworth v. Zerbst, 98 F.2d at 544).

133. Monroe v. Pape, 365 U.S. at 187.

134. Sparks v. Duval County Ranch Co., 604 F.2d at 980.

135. See Developments in the Law 1135.

136. See notes 16-17 supra and accompanying text. Several of the arguments supporting the doctrime are not tailored to the concept of derivative immunity but instead have been listed in other contexts as reasons for restricting the section 1983 action. See Comment, The Evolution of the State of Mind Requirement of Section 1983, 47 TUL. L. REv. 870, 885 (1973) ("Arguments in favor of restricting the availability of a federal forum are as follows: . . the federal courts will become clogged with trivial hitigation . . . and . . . the federal courts will be injected into the area of local police regulation thereby upsetting the balance of authority in the federal-state relationship").

137. See text accompanying note 16 supra. 
be met and the suit nust be dismissed. ${ }^{138}$ This reasoning of courts that have adopted the derivative immunity doctrine inplicitly accepts the following theory: (1) section 1983 requires state action; (2) when the complaint is against a private party, liability will follow only if the private party conspired with a state official; (3) if, however, the state official is immune, the plaintiff cannot state a cause of action against him; and (4) the state action therefore vanishes and the plaintiff's suit must be dismissed.

The requirement that the plaintiff be able to state a valid claim agamst the public defendant, however, arises from the courts' confusion of the concepts of immunity for a state official and state action. State action is clearly an essential jurisdictional prerequisite for a section 1983 claim. When it is lacking, the complaint slould be disinissed for lack of subject matter jurisdiction. "Alternatively a question of whether a defendant is immune, either qualifiedly or absolutely, is not a jurisdictional issue. Rather, immunity is an affirmative defense which may defeat the section 1983 claim once that subject inatter jurisdiction has been established." 139 As the Fifth Circuit has recently recognized,

[a state official's] immunity from the damages remedy [does] not in any manner [affect] his capacity to conspire . . . . In assaying for state action, the question is not at all whether the agent of the state who acts is subject to any particular sanction. Rather, it is whether he has exercised the power of the state . . . 140

The decision in Russell v. Town of Mamaroneck ${ }^{141}$ illustrates the confusion of the immunity and state action concepts. In two related actions, plamtiffs sought injunctive and declaratory judgenents against a township and private defendants for authorizing private parties to place nativity scenes on public lands. The plamtiffs premised federal jurisdiction on 28 U.S.C. $\S 1343(3),{ }^{142}$ the jurisdictional counterpart of section 1983. The court found jurisdiction to be lacking because the inunicipal defendants were not "persons" within the meaning of section 1983,143 and thus were immune froin suit. In turn, the court held that "it is not possible that the private defendants acted under color of state law on the basis of joint activity with the public defendants." 144

138. See note 79 supra and accompanying text.

139. Robinson v. Bergstroin, 579 F.2d 401, 404 (7th Cir. 1978) (per curiam).

140. Sparks v. Duval County Ranch Co., 604 F.2d at 982.

141. 440 F. Supp. 607 (S.D.N.Y. 1977).

142. 28 U.S.C. $\S 1343(3)$ (1976).

143. Russell was decided before the Supreme Court's decision in Monell. See notes 83-84 supra and accompanying text.

144. $440 \mathrm{~F}$. Supp. at 612 (emphasis added). 
Clearly, state action cannot simply be erased by the absence of the public actor as a defendant due to his immunity. ${ }^{145}$ Under section 1983, state action and immunity are two separate issues. Analysis, therefore, properly should be conducted in two stages. First, the court should examine the statutory requirements for a section 1983 claim: state action and deprivation. Second, it should evaluate the defenses available to each defendant, on a defendant-by-defendant basis. The derivative immunity doctrine, however, unjustifiably inixes these concepts by requiring the absence of an immunity defense as a prerequisite to, and thereby an element of, state action.

\section{The Arbitrary Nature of the Derivative Immunity Defense.}

As the derivative immunity defense is currently applied, the destiny of the private defendant is initially contingent not upon his own acts, but upon the acts of the public co-conspirator. Whether the private defendant receives any measure of immunity is entirely dependent upon the liability of the public official with whom he has acted. ${ }^{146}$ In inany instances, this determination of the public official's inmunity will create a windfall defense for the private party ${ }^{147}$ and deny the aggrieved party any relief under section 1983. In short, the defendant's guilt is initially contingent upon matters over which the defendant has no control. The derivative immunity doctrine demonstrates its manifest injustice by pernitting this arbitrary determination of liability.

\section{A Doctrine in Limbo.}

The foregoing analysis illustrates that the doctrine of derivative immumity cannot withstand a careful examination based on policy or theory. In addition, several individual judges ${ }^{148}$ have noted that the Supreine Court's decisions in United States v. Price ${ }^{149}$ and Adickes v. S.H. Kress \& Co. ${ }^{150}$ which postdate Haldane, undercut the artificial precedent for the doctrine. Both decisions establish that private indi-

145. Downs v. Sawtelle, 574 F.2d 1, 15 (1st Cir.), cert. denied, 439 U.S. 910 (1978). Similarly, the removal of a co-conspirator as a defendant does not erase the conspiracy. See text accompanying notes 131-32 supra.

146. See "Vicarious Immunity" 1037.

147. Sparkman v. McFarlin, 601 F.2d at 274 (Swygert, J., dissenting).

148. Sparkman v. McFarlin, 601 F.2d at 27 I n.5 (Swygert, J., dissenting); Slotnick v. Staviskey, 560 F.2d 31, 33 n.l (Ist Cir. 1977) (Coffin, C.J., "speaking only for himself"), cert. denied, 434 U.S. 1077 (1978).

149. 383 U.S. 787 (1966). See notes 4-6 supra and accompanying text.

150. 398 U.S. 144 (1970). In Adickes, the Court upheld the sufficiency of a section 1983 complaint in which the plaintiff alleged a conspiracy between a store owner and the local police to deprive her of equal protection of the law on the basis of race. 
viduals who conspire with state officials are acting under color of state law regardless of whether the state official is joined in the suit. Therefore, private parties should be hable under section 1983 for conspiracy with state officials, even if the officials are not and cannot be named as defendants in the suit.

Not surprisingly, when the doctrine has been carefully reasoned, it has fallen into disfavor. ${ }^{151}$ One court of appeals, however, has suggested a novel approach for curtailing the doctrine of derivative immunity without expressly overturning it. This approach is discussed in the following section.

\section{The Elevated (Strict) Pleading Standard}

\section{A. The Seventh Circuit's Suggestion.}

The Court of Appeals for the Seventh Circuit suggested an alternate approach to the doctrine of derivative immunity in Sparkman $v$. McFarlin. ${ }^{152}$ While avoiding the derivative immunity issue, the court dismissed a section 1983 claim for failure to allege with sufficient particularity facts that would show a conspiracy between an immune state official and private persons.

In Sparkman, the complaint arose from the sterilization of the plaintiff when she was fifteen years old. The plaintiff's inother, concerned by her daughter's apparent proiniscuity and slowness in learn$\mathrm{mg}$, petitioned an Indiana state judge to have a tubal higation perforined on her daughter, to "prevent unfortunate circumstances."153 The judge approved the petition, which included a covenant indemnifying the hospital and doctors in any legal action, without a hearing and without appointing a guardian ad litem for the plamtiff. ${ }^{154}$ Subsequently, the plaintiff was adinitted to the hospital, having been told that her appendix would be removed. Instead, the tubal ligation was perforined and she was released, unaware of the true nature of her sur-

151. The doctrine has been specifically rejected in the First, Fifth, and Tenth Circuits and its vahidity in the Seventh Circuit is currently very uncertain. See notes 26-29 supra \& 159-65, 199214 infra and accompanying text. Even in the Ninth Circuit, where the doctrine had its origin in Haldane, "[i]t is [currently] unclear whether a private party who conspires with a state official who is clothed with immunity is liable under $\S 1983$. . . " Briley v. California, 564 F.2d 849, 858 n.10 (9th Cir. 1977).

152. 601 F.2d 261 (7th Cir. 1979) (per curiain) (en banc).

153. Sparkman v. McFarlin, 552 F.2d 172, 173 (7th Cir. 1977), rev'd sub nom. Stuunp v. Sparkman, 435 U.S. 349 (1978). For a full statement of the facts as developed on appeal, see $552 \mathrm{~F} .2 \mathrm{~d}$ at 173-74.

154. In A.L. v. G.R.H., 163 Ind. App. 636, 325 N.E.2d 501 (1975), a decision handed down after the sterilization of the plaimtiff in Sparkman, the Indiana court held that a parent does not possess a common law right to have a minor child sterilized, even though the parent unight "sincerely beheve the child's adulthood would benefit therefrom." Id. at 638, 325 N.E.2d at 502 . 
gery. Two years later, after being informed of her sterility, the plaintiff filed a section 1983 suit naming as defendants her mother, the mother's attorney who drafted the petition to sterilize, the state court judge who approved the petition, the three doctors who performed or assisted in the sterilization, and the hospital in which the surgery was performed. In dismissing the complaint, the district court found the judge absolutely immune and extended his immunity derivatively to destroy any action, ${ }^{155}$ thus barring the claims against the private defendants. ${ }^{156}$ The Seventh Circuit reversed, holding that the judge was not entitled to immunity because he had acted extrajudicially and that the claims against the other defendants were therefore valid.157 The Supreme Court reversed the decision again, finding that the state judge had not acted in a clear absence of jurisdicition and that he was therefore entitled to judicial immunity. ${ }^{158}$ The Supreme Court remanded the case for further proceedings on the liability of the private defendants and thus did not address the validity of the derivative immunity doctrime.

In a per curiain opinion, the Seventh Circuit, sitting en banc, affirmed the district court's disinissal of the claims against the private defendants. ${ }^{159}$ Although the opinion inerely affirmed the opinion of the district court, two concurring opinions expressly suggested that an elevated pleading standard be apphied to section 1983 claims against private defendants alleged to have conspired with immune public officials. ${ }^{160}$ A inajority of the panel agreed that the complaint in this case failed to allege a conspiracy with sufficient specificity.

In the plurality opinion, ${ }^{161}$ written by Judge Sprecher, the court

155. The holding of the district court is another example of the confusion between state action and the immunity of a state official. See text accompanying notes 137-45 supra.

156. Sparkman v. McFarlin, Civ. No. F 75-129 (N.D. Ind. May 13, 1976), rev'd, 552 F.2d 172 (7th Cir. 1977), rev'd sub nom. Stump v. Sparkman, 435 U.S. 349 (1978).

157. Sparkman v. McFarlin, 552 F.2d 172 (7th Cir. 1977), rev'd sub nom. Stump v. Sparkman, 435 U.S. 349 (1978).

158. Stump v. Sparkman, 435 U.S. 349 (1978).

159. 601 F.2d 261 (7th Cir. 1979) (per curiam) (en banc). The court's opimion was highly divided. In addition to the per curiam opinion, three concurring opinions and one dissenting opinion were issued, with each of the remaining four judges joining either a concurrence or the dissent. The eight judges were equally divided on the question of derivative immunity.

160. Id. at 262 (Fairchild, C.J., concurring); id. at 263 (Sprecher, J., concurring).

161. Although the per curiani opimion merely affirms the district court decision, Judge Sprecher's opinion was the most well-reasoned of the concurrences supporting the affirmance and his opinion will be designatcd as the plurality decision for the purposes of this Comment. Judge Sprecher's opinion called for both the abandonment of derivative immunity and the application of a strict pleading standard. The court was divided on both issues. Chief Judge Fairchild and Judge Sprecher expressly favored an elevated pleading standard while Judges Swygert, Cuminings, Sprecher, and Wood were opposed to derivative immunity. Five members of the eightmeinber panel, therefore, agreed with at lcast part of Judge Sprecher's opinion. Judges Pell, Bauer, and Tone did not feel that the complaint containcd sufficient allegations of a conspiracy, 
noted that before a private person can be found liable, a nexus with the state, one of its entities, or one of its officials must be shown. ${ }^{162}$ Relying on Adickes v. S.H. Kress \& Co. ${ }^{163}$ the plurality required that "the private party '[reach] an understanding' through a meeting of the minds" with the state official. 164 The failure of the pleadings to list specific facts to show this level of conspiracy, the requisite nexus, should render the complaint conclusory and insufficient. The plurality implied that if the factual particulars could be alleged, private persons might be exposed to section 1983 liability, despite the immunity of the government co-conspirator. ${ }^{165}$

\section{B. Close Scrutiny or an Elevated Requirement?}

Careful scrutiny of pleadings to screen out insubstantial complaints is not novel in the context of section 1983 conspiracy claims. ${ }^{166}$ This review, however, is used only to insure that the statutory requirements-some form of state action and a deprivation of a constitutional right-are alleged. ${ }^{167}$ Allegations of overt acts that are reasonably related to the promotion of the claimed conspiracy have always been required, ${ }^{168}$ but not allegations of a meetmg of the minds. Alleging overt, cvidentiary acts of a conspiracy is certamly less burdensome to the plaintiff than averring the alleged conspirators' state of mimd. Typical complaints that have been dismissed as conclusory under careful scrutimy are those in which the allegations in the complaint detail the course of state litigation and conclude that a conspiracy must have been afoot for such a result to liave been obtained. ${ }^{169}$

but they stopped short of expressly calling for an elevated standard of pleading. See id. at $269 \mathrm{n} .1$ (Swygert, J., dissenting).

162. Id. at 264 (Sprecher, J., concurring).

163. 398 U.S. 144 (1970).

164. 601 F.2d at 264 (Sprecher, J., concurring).

165. Id. at 266.

166. See, e.g., Slotnick v. Staviskey, 560 F.2d 31, 33 (1st Cir. 1977), cert. denied, 434 U.S. 1077 (1978); Grow v. Fisher, 523 F.2d 875, $878-79$ (7th Cir. 1975); Croy v. Skinner, 410 F. Supp. 117, 126 (N.D. Ga. 1976).

167. This scrutimy of the pleadings is similar to the type recommended previously. See text accompanying note 112 supra.

168. See, e.g., Morales v. Vega, 579 F.2d 677, 680 (1st Cir. 1978); Kadar Corp. v. Milbury, 549 F.2d 230, 233 (1st Cir. 1977); Powell v. Workmen's Compensation Bd., 327 F.2d 131, 137 (2d Cir. 1964); Croy v. Skinner, 410 F. Supp. 117, 126 (N.D. Ga. 1976); Byrd v. Local 24, IBEW, 375 F. Supp. 545, 558 (D. Md. 1974). This close scrutmy (as opposed to a strict pleading standard) appears to have been adopted by the Fifth Circuit in two cases decided after Sparkman. See Henzel v. Gerstem, 608 F.2d 654, 659 (5th Cir. 1979); Sparks v. Duval County Ranch Co., 604 F.2d at 978.

169. See, e.g., Ellentuck v. Klein, 570 F.2d 414, 426 (2d Cir. 1978); Powell v. Workmen's Compensation Bd., 327 F.2d at 137. 
In comparison to the typical careful scrutiny, the plurality opinion in Sparkman imposes a stricter pleading threshold. ${ }^{170}$ The Sparkman plurahty would require additional specificity about the co-conspirators'

170. There are several reasons for concluding that the plurality, and possibly a majority of the court, sought in Sparkman to establish an elevated pleading requirement. First, the language in the concurring and dissenting opinions indicates that a more exacting standard is in fact required. Chief Judge Fairchild stated, "I would build into any principle for the recognition of a $\$ 1983$ claim based on a private person's conspiracy with a state judge, a requirement of pleading and proof ... that there was agreement between the party and the judge . .." 601 F.2d at 262 (Fairehild, C.J., concurring). Judge Sprecher claimed that disposing of the liability of private parties by requiring particularity in alleging a conspiracy has allowed the court to avoid taking a position on the doctrine of derivative immunity. Id. at 266 (Sprecher, J., concurring). In addition, Judge Swygert, in lis dissent, was convimced that the plurality applied "a new and more demanding pleading requirement" than is required by the Federal Rules of Civil Procedure. Id. at 275 (Swygert, J., dissenting).

Second, in Baer v. Baer, 450 F. Supp. 481 (N.D. Cal. 1978), the district court implied that when a section 1983 conspiracy is alleged between private parties and state officials, additional facts must be pleaded if the state official involved is immune. See id. at 488-89. Like Sparkman, Baer involved a section 1983 complaint lodged by a child against his parent. The plaintiffs parents had obtained the assistance of a state court and a private organization in their effort to deprogram the plaintiff, who was a follower of the Reverend Sun Myung Moon and a meinber of the Unification Church. In dismissing the complaint for failure to state a claim, the court held that a private plaintiff would "have to allege sufficient facts to overcome the immunity fron liability courts liave granted public officials in $\S 1983$ suits." Id. at 488 (emphasis added). Significantly, the district court in Baer sat in the Ninth Circuit, which developed the concept of derivative immunity in Haldane. See notes 11-17 supra and accompanying text. Recently, however, the Ninth Circuit has limted that the validity of the doctrine is somewhat in question there. See note 151 supra. Given the uneasiness in both the Seventh and Ninth Circuits over the doctrine, it appears that the Sparkman court, like the Baer court, was trying to steer a middle course away from derivative immunity without expressly rejecting it.

Third, when the Seventh Circuit first received the Sparkman case on appeal, it held that the state judge was not immune, but never questioned the sufficiency of the pleadings. In addition, the sufficiency of the pleadings had not been questioned by the district court. $601 \mathrm{~F} .2 \mathrm{~d}$ at 281 (Swygert, J., dissenting). On remand from the Supreme Court, however, five of the judges (a majority), in concurring opmions, stated that the pleadings were imsufficient to state a section 1983 claim. See note 161 supra. Because the case was not dismissed for insuficient pleadings when first received, the court, on remand, must have been announcing a new pleading standard.

Finally, the pleadings in Sparkman appear to meet the requirements of the Federal Rules of Civil Procedure. See 601 F.2d at 275 n.14 (Swygert, J., dissenting). For exainple, paragraph 30 of the complaint provided:

The actions of Defendants . . . in concert and with the common goal and result of sterilizing Linda Kay Sparkman, deprived said Linda Kay Sparkman of her constitutional and statutory rights to privacy, to the equal protection of the laws and to not be deprived of life or property without the due process of law.

Id. at $268 \mathrm{n.8}$ (Sprecher, J., concurring). In addition, the pleadings are more specific than those that have been upheld as sufficient in other circuits. See, e.g., Downs v. Sawtelle, 574 F.2d 1, 15 (1st Cir.), cert. denied, 439 U.S. 910 (1978) (sterilization case sinilar to Sparkman; complaint alleging concerted action between private defendants and public officials, some of whoin were inmune, held sufficient to state a section 1983 cause of action based on conspiracy); Fine v. City of New York, 529 F.2d 70, 72 (2d Cir. 1975) (allegation that plaintiff's private attorney cooperated with police and failed to identify himself as plaintiff's attorney during an unlawful search of his client's apartment held sufficient to state a seetion 1983 cause of action for conspiracy agamst attorney). 
meeting of minds, but only in a section 1983 conspiracy complaint against a private party when his public co-conspirator is immune from suit. Presumably, when the public official is not immune, such specificity in the pleadings would not be required. The obvious purpose of this strict pleading rule is to avoid the issue of derivative immunity. As the plurahity opinion reveals, the court is looking for a rule that is flexible enough to accominodate the policy considerations on both sides of the question. ${ }^{171}$ The requirement of fact-specific pleading, however, overlooks an important, competing policy embodied in the Federal Rules of Civil Procedure.

\section{A Critique of the Strict Pleading Test.}

Analysis of the specific pleading requirement suggested by the Seventh Circuit in Sparkman indicates that it is imconsistent with the Federal Rules of Civil Procedure. Under rule 8(a)(2), a pleadimg need only contaim "a short and plain statement of the claim showing that the pleader is entitled to rehef." 172 The most important feature of rule 8(a) is the substitution of "a short and plaim statement" for the prior code formula, "facts constituting a cause of action."173 As the Supreme Court has stated in its frequently cited Conley v. Gibson ${ }^{174}$ opinion, "the Federal Rules of Civil Procedure do not require a claimant to set

171. $601 \mathrm{~F} .2 \mathrm{~d}$ at 267 (Sprecher, J., concurring). The strict pleading standard is a middle ground, providing a remedy only when a section 1983 violation clearly exists. Id. at 267-68. As has been noted, however, careful scrutiny will suffice to screen out many frivolous suits. See notes 112 \& 166-69, supra and accompanying text. Further, section 1983 should not be restricted to the clear case; when the question of liability is close, it should go to the jury. See notes 195-96 infra and accompanying text.

172. Rule 8(a)(2) provides: "A pleading which sets forth a claim for relief, whether an original claim, counterclaim, cross-claiın, or third-party claim, shall contain . . . a short and plain statement of the claim showing that the pleader is entitled to relief." FED. R. Civ. P. 8(a)(2).

173. 5 C. WRIGHT \& A. MILLER $§ 1202$, at 59 . In contrast to the broad general pleadings of rule 8, rule 9 catalogs several special matters that inust be pleaded witl specificity. Rule 9 requires that "[i]n all averments of fraud or mistake, the circumstances constituting fraud or mistake shall be stated with particularity." FED. R. CIV. P. 9(b). A variety of reasons have been given for the detailed pleading requirements of fraud and mistake. Among them are claims that

[a]llegations of fraud or mistake frequently are advanced only for their nuisance or settlement value and with little hope that they will be successful. . . . Also, fraud and mistake embrace such a wide variety of potential conduct that a defendant needs a substantial amount of particularized information about plaintiffs claim in order to enable him to understand it and effectively prepare his response.

5 C. WRIGHT \& A. MILLER $\S 1296$, at 399-400. Although conspiracy, like fraud, is a conclusion of law, it embraces a much narrower variety of conduct than does fraud. A defendant, therefore, would need less particularized information when charged with civil conspiracy than with fraud. More important, the fraud and mistake provisions of rule 9 operate as an exception to the general rule of notice pleading under rule 8. Conspiracy is not histed in rule 9 as one of the specific exceptions to rule 8. By negative implication, therefore, particularized facts need not be pleaded in an averment of conspiracy under the Federal Rules of Civil Procedure.

174. 355 U.S. 41 (1957). 
out in detail the facts upon which he bases his claim."175 Rather, they require only that the defendant be given "fair notice of what the plaintiff's claim is and the grounds upon which it rests."176 Significantly, the Supreme Court has mdicated that this same level of specificity pertains to section 1983 complaints. ${ }^{177}$ Great generality, therefore, is permitted in the pleadings as long as the defendant is given fair notice of the basis of the claim. ${ }^{178}$

Fair notice under the Federal Rules, of course, does contemplate a statement of circumstances, occurrences, and events in support of the clami presented. ${ }^{179}$ More detail is required than a bald statement by the plaimtiff "that he has a valid claim of some type." 180 What must be pleaded ultimately depends on the nature of the complaint itself. A prima facie case of civil conspiracy consists of three elements: a combination of two or more persons acting in concert unlawfully, an agreement between the parties "to inflict a wrong agamst or injury to another,"181 and "an overt act that results in damage."182 Clearly the most difficult element to prove is the agreement. In a case mvolving a section 1983 claim decided nine days before Sparkman, the Seventh Circuit recognized that "[a]n express agreement among all the conspirators is not a necessary element of a civil conspiracy."183 To demonstrate the existence of a conspiratorial agreement it need only be shown that there was "a single plan, the essential nature and general scope of which [was] known to each person who is to be held responsible for its

175. Id. at 47 .

176. Id.

177. See Scheuer v. Rhodes, 416 U.S. 232, 236 (1974). See text accompanying notes 191-92 infra.

178. 5 C. WRIGht \& A. Miller $\S 1202$, at 64. Professors Wright and Miller have noted that "[u]nder the federal rules it is very difficult for counsel to draft a pleading so badly as to lose the rights of his clients. Indeed, it has been said that 'a sixteen year old boy could plead' under these rules." $I d . \S 1202$, at 65 (quoting Cleveland InStitute on the Federal Rules, Proceedings 220 (1938)).

179. 5 C. WRIGHT \& A. MiLLER $\$ 1202$, at 64.

180. Id. $\$ 1357$, at 596 .

181. Hampton v. Hanrahan, 600 F.2d 600, 620-21 (7th Cir. 1979) (quoting Rotermund v. United States Steel Corp., 474 F.2d 1139 (8th Cir. 1973)). The elements of civil conspiracy apply to a section 1983 conspiracy.

182. Hampton v. Hanrahan, 600 F.2d at $620-21$.

183. Id. at 621 ("The participants in the conspiracy must share the general conspiratorial objective, but they need not know all the details of the plan designed to achieve the objective or possess the same motives for desiring the intended conspiratorial result"). Hampton is revealing because the Seventl Circuit applied a more liberal pleading standard for conspiracy in that case than it did in Sparkman. Unlike Sparkman, Hampton did not involve private defendants or findings of immunity on behalf of the public defendants. 
consequences."184 A plaintiff need not show that each participant in the conspiracy knew "the exact limits of the illegal plan or the identity of all participants therein." 185

In spite of the foregoing, the Seventh Circuit in Sparkman apparently required the section 1983 plaintiff to plead with particularity that the private party attained a ineeting of the minds with the immune state official or officials. ${ }^{186}$ By seeking an alternative to the doctrine of derivative immuinty, the plurality in Sparkman utilized a strict pleading requirement that confuses what the plaintiff inust plead in the coinplaint with what the plaintiff inust show at trial. ${ }^{187}$ In essence, the elevated pleading standard would require the plaintiff to plead with specificity an eleinent of the case that would be dispositive of the clain. This certainly goes far beyond the notice requirement of rule 8(a). ${ }^{188}$ The Supreme Court's language in Adickes v. S.H. Kress \& Co. ${ }^{189}$ which the Seventli Circuit cited in Sparkman, reveals the flaw in the court's approach: "[P]etitioner will have made out a violation of her Fourteenth Amendinent rights and will be entitled to relief under $\S 1983$ if she can prove that a [store] einployee ... and a [city] pohiceman somehow reached an understanding . . . ."190

In Scheuer $v$. Rhodes, ${ }^{191}$ the Supreme Court reasoned that the requirements for pleading a civil conspiracy are different from and more liberal than the requirements for proving a conspiracy. The Court instructed:

When a federal court reviews the sufficiency of a complaint,

184. Hoffman-LaRoche, Inc. v. Greenberg, 447 F.2d 872, 875 (7th Cir. 1971), quoted with approval in Hampton v. Hanrahan, 600 F.2d at 621.

185. Hoffman-LaRoche, Inc. v. Greenberg, $447 \mathrm{~F} .2 \mathrm{~d}$ at 875 , quoted will approval in Hampton v. Hanrahan, 600 F.2d at 621 .

186. See notes 159-165 supra and accompanying text.

187. Although the reason for the confusion is not clear, it is possibly due to the derivative nature of the state action requirement in section 1983 conspiracy cases. In these cases, the under color of law requirement must be derived from the conspiracy. The conspiracy in turn must be derived, at least in part, from the existence of an agreement, which in turn is dependent on some form of meeting of the minds. Thus, the meeting of the minds is thrice removed froin the state action requirement.

188. It is important to note that the Sparkman court was disınissing the complaint for failure to state a claim. This was not a ruling upon a motion for summary judgment. General allegations are insufficient to win summary judgment. Rule 56(e) of the Federal Rules of Civil Procedure provides that, in inaking a motion for summary judgment, "an adverse party inay not rest upon the mere allegations or denials of his pleading, but his response . . . must set forth specific facts showing that there is a genuine issue for trial." FED. R. Civ. P. 56(e). In addition, the dismissal in Sparkman was not the result of a motion for a more definite statement of the complaint under rule 12(e).

189. 398 U.S. 144 (1970).

190. Id. at 152 (emphasis added).

191. 416 U.S. 232 (1974). 
before the reception of any evidence by affidavit or admissions, its task is necessarily a limited one. The issue is not whether a plaintiff will ultimately prevail but whether the claimant is entitled to offer evidence to support the claims. Indeed it may appear on the face of the pleadings that a recovery is very reinote and unlikely but that is not the test. ${ }^{192}$

The Supreine Court has also declared that in passing on the sufficiency of the pleadings courts should construe the allegations in the complaint favorably to the pleader, and that a complaint should not be dismissed "unless it appears beyond doubt that the plaintiff can prove no set of facts in support of his claim which would entitle him to relief."193 This liberal construction is especially applicable to a charge of conspiracy. "In inany cases of conspiracy essential information can only be produced through discovery, and the parties should not be thrown out of court before being given an opportunity through that process to ascertain whether the linkage they think may exist actually does."194

Thus, the liberal requirements of the Federal Rules would require a dismissal only when the complaint is clearly deficient. The strict pleading test suggested in Sparkman, however, by adhering to a fairly strict standard for pleading and proof, would restrict section 1983 liability to those situations in which a "coinpeting interest-the need to vindicate violated constitutional rights-clearly, exists."195 The close case would be taken away from the jury. This is clearly contrary to the Supreine Court's assertion that when a plaintiff alleges a conspiracy to violate civil rights, "[t] he existence or nonexistence of a conspiracy is essentially a factual issue that the jury, not the trial judge, should decide." 196

If the strict pleading standard enunciated by Sparkman is ineant to be an exception to the general rule under the Federal Rules of Civil Procedure, it is nevertheless doubtful that it would accoinplish the goal

192. Id. at 236.

193. Conley v. Gibson, 355 U.S. $41,45-46$ (1957) (citation omitted).

194. Lessman v. McCormick, 591 F.2d 605, 611 (10th Cir. 1979).

195. 601 F.2d at 267-68.

196. Adickes v. S.H. Kress \& Co., 398 U.S. 144, 176 (1970) (Black, J., concurring). The Seventh Circuit has expressly recognized the vahdity of this point. See Hampton v. Hanrahan, 600 F.2d at 621 . It has even gone a step further and held that

the question whether an agreement exists should not be taken from the jury in a civil conspiracy case so long as there is a possibility that the jury can "infer from the circuunstances [that the alleged conspirators] had a 'meeting of the minds' and thus reached an understanding to achieve the conspiracy's objectives."

Id. (quoting Adickes v. S.H. Kress \& Co., 398 U.S. at 158-59). Hampton, however, did not involve a conspiracy between private parties and public officials; this fact gives added support to the assertion that Sparkman employs a separate test for plaintiffs seeking to recover agaimst private parties when the public official involved is immune. See notes $170 \& 183$ supra. 
of screening frivolous lawsuits. "[E]recting a pleading barrier between the courtrooln and ungrounded lawsuits is likely to be an unsatisfactory ineans of avoiding frivolous litigation, since persons disposed to bring such hitigation would probably have little difficulty explicating their alleged grievances with particularity." 197

The elevated pleading standard suggested by the Seventh Circuit inay also, sub silentio, alter the substantive law of civil conspiracy in an atteinpt to salvage a needless doctrine. It has been suggested that a fact-specific pleading requireinent may necessitate direct evidence of a conspiracy and thus foreclose the use of circumstantial evidence. ${ }^{198}$

While less offensive than the absolute bar of derivative immunity, a strict pleading requirement would nonetheless operate to block at least some worthy claims. This requirenent, like derivative immunity, would be triggered by events over which the private defendant has no control. The private defendant benefitting from the strict pleading requirement would do so only because of the fortuitous circumstance that the public official with whoin he acted was immune. If the public coconspirator were not immune, the elevated pleadings would not be required. At best, the strict pleading test is a compromise. The compromise of an unncecessary doctrine, however, can hardly be embraced.

\section{Strict Liability Approach}

The Court of Appeals for the First Circuit has consistently rejected

197. Sparks v. Duval County Ranch Co., 604 F.2d at 989 (Coleman and Ainsworth, JJ., dissenting).

198. See Sparkman v. McFarlin, 601 F.2d at 279 (Swygert, J., dissenting). Under the substantive law of civil conspiracy, proof of the conspiracy may be provided by circumstantial evidence, since conspirators rarely formulate their plans in ways susceptible of proof by direct evidence. Crowe v. Lucas, 595 F.2d 985, 993 (5th Cir. 1979); Ferguson v. Omnimedia, Inc., 469 F.2d 194, 198 (1st Cir. 1972); Hoffman-LaRoche, Inc. v. Greenberg, 447 F.2d 872, 875 (7th Cir. 1971). The facts in Crowe are to some extent sunilar to those in Sparkman. The results of the cases, however, are very different. In Crowe, the court held that the evidence "showed that the defendants had participated in private ineetings at which [the plaintiff] was discussed. From this evidence and the testimony regarding the defendant's course of conduct toward [the plaintiff], the jury could reasonably have inferred that a conspiracy existed." 595 F.2d at 993.

In Adickes v." S.H. Kress \& Co., 398 U.S. 144 (1970), the Supreme Court noted that the conspiracy claim was based not on allegations of facts demonstrating a meeting of the minds, but instead on the argument that "although [the plaintiff] had no knowledge of an agreement between [the private defendant] and the police, the sequence of events created a substantial enough possibility of a conspiracy to allow [plaintiff] to proceed to trial." Id. at 157, quoted in Sparkman $v$. McFarlin, 601 F.2d at 280 (Swygert, J., dissenting). The requirement that a plaintiff who is alleging a conspiracy between a private party and an immune public official state facts that specifically demonstrate a meeting of the minds necessitates direct evidence of the conspiracy in the pleadings. Under the current law of civil conspiracy, however, only circumstantial evidence of the conspiracy need be shown at trial. 
the doctrine of derivative immunity. ${ }^{199}$ In Downs $v$. Sawtelle, ${ }^{200}$ the First Circuit announced its requirements for a prima facie cause of action for a section 1983 complaint against a private party alleged to have conspired with an immune public official. The court held that "once the requisite showing of concerted action is made, and assuming that some colorable constitutional deprivation is made out, the injured party has an independent cause of action for damages against the private party involved."201

The initial pleading requirements for a section 1983 conspiracy in the First Circuit, therefore, are an allegation of concerted action, evidence of an overt act, and a colorable constitutional deprivation. ${ }^{202} \mathrm{~A}$ pleading of specific facts tending to show a ineeting of the ininds is not required. In light of the Federal Rules of Civil Procedure ${ }^{203}$ and the circuunstantial manner in which a conspiracy can be shown, ${ }^{204}$ the First Circuit approach is clearly preferable to a strict pleading test. Adequate and fair notice, the purpose of rule 8(a)(2), is given to the defendants, and the plaintiff is correspondingly entitled to discovery. In the section 1983 claim based on conspiracy, discovery is probably critical to the plaintiff's case.

Moreover, the First Circuit has rejected any form of qualified immunity that would be apphied to private persons independently of the immunity of state officials. ${ }^{205}$ Adhering closely to the Supreme Court's instructions in Monroe, the First Circuit unaintams that section 1983 "should be read against the background of tort liability that inakes a man responsible for the natural consequences of his actions."206 In the context of section 1983, this imposes a strict liability standard on pri-

199. Downs v. Sawtelle, 574 F.2d 1, 15 (1st Cir.), cert. denied, 439 U.S. 910 (1978); Slotnick v. Staviskey, 560 F.2d 31, 32 (1st Cir. 1977), cert. denied, 434 U.S. 1077 (1978); Kermit Constr. Corp. v. Banco Credito Y Ahorro Ponceno, 547 F.2d 1, 3 (1st Cir. 1976).

200. 574 F.2d 1 (1st Cir.), cert. denied, 439 U.S. 910 (1978).

201. 574 F.2d at 15 .

202. See also Skyes v. California, 497 F.2d 197, 200 (9th Cir. 1974). These pleading requireinents are consistent with the Supreine Court's holding in Adickes v. S.H. Kress \& Co., 398 U.S. at 152. See note 150 supra. In that case the Court held that for a private party to have acted under color of state law, "[i]t is enough that he [was] a willful participant in joint activity with the State or its agents ...." Courts that have rejected the concept of derivative immunity have relied heavily on the Adickes decision. See, e.g., Sparks v. Duval County Rancli Co., 604 F.2d at 982-83; Downs v. Sawtelle, 574 F.2d at 15.

203. See notes 172-97 supra and accompanying text.

204. See note 198 supra.

205. Downs v. Sawtelle, 574 F.2d at 16 ("We loold that the Wood defense is not available to [the private defendant] and that her liabihty is to be determined by the jury without regard to any claim of good faith"). See text accompanying note 63 supra for a discussion of Wood v. Strickland, 420 U.S. 308 (1975).

206. Downs v. Sawtelle, 574 F.2d at 15 (quoting Monroe v. Pape, 365 U.S. at 187). Monell v. Department of Social Servs., 436 U.S. at 701, only overturned Monroe to the extent that it held 
vate persons acting in concert with state officials to deprive another of rights secured by the Constitution. ${ }^{207}$

The Court of Appeals for the Fifth Circuit, in Sparks v. Duval County Ranch Co., ${ }^{208}$ has also expressly rejected the doctrine of derivative immunity. This recent decision reversed a long line of section 1983 cases in the Fifth Circuit that had upheld the doctrine. ${ }^{209}$ In Sparks, a state court judge had entered an injunction prohibiting the plaintiffs from producing a particular supply of oil. The plaintiffs brought a section 1983 action, claimmg that the judge and four private party defendants had conspired to deprive the plaintiffs of their oil production. Because the judge was absolutely immune, the district court, operating under the derivative immunity doctrine, disinissed the complaint

municipalities not to be "persons" within the meaning of section 1983. See notes 84-92 supra and accompanying text.

207. In section 1983 case law prior to Monroe, the courts generally required that the defendant specifically intend to deprive the plaintiff of a constitutionally protected right. They read a purposive intent requirement imto the statute by analogizing section 1983 to its criminal counterpart, 18 U.S.C. $\$ 242$, (1976), see note 5 supra, which explicitly requires the defendant to act wilfully before crininal liabihty can be found. Comment, supra note 136, at 871. In Monroe, however, the Supreme Court read section 1983 hterally and rejected the wilfull requirement as an element of the cause of action. Writing for the majority, Mr. Justice Douglas noted: "The word 'wilfully' does not appear in [section 1983. The statute] should be read against the background of tort hability that makes a inan responsible for the natural consequences of his actions." 365 U.S. at 187. It is unclear, however, whether Monroe considered to what extent, if any, the defendant's state of mind was relevant to liability under the statute. As one commentator has noted:

The phrases "background of tort liability" and "responsible for the natural consequences of his actions" can be read to refer to different concepts within the law of torts. On the one hand, "background of tort liability" can be interpreted to refer to the tort principle of fault, where liability exists only for dannages caused through the fault of the actor. On the other hand, "responsible for the natural consequences of his actions" would appear to refer to a standard of strict liability.

Comment, supra note 136 , at 875.

The post-Monroe position of the lower federal courts on the state of mind requirement in section 1983 cases has been varied. Soine courts have applied a tort fault, or negligence, approach. See, e.g., Roberts v. Williams, 456 F.2d 819, 826 (5th Cir.), cert. denied, 404 U.S. 866 (1971). Others have not required fault as a prerequisite to liability. See, e.g., Whirl v. Kern, 407 F.2d 781, 787-88 (5th Cir. 1969). In addition, the pre-Monroe purposeful intent requirement may still enjoy some support. See, e.g., Beauregard v. Wingard, 230 F. Supp. 167, 183 (S.D. Cal. 1964). For a discussion of these various approaches, see Comment, supra note 136, at 876-81. It should be noted that these approaches arose mainly in the context of the liability of public defendants under section 1983.

The better position on this issue is the strict liability approach. A literal interpretation of the statute's requirements would deinand this result. More important, "[t]he strict liability approach is the only alternative that satisfactorily coinplies with both of the theories of deterrence and compensation" that underhe section 1983. Coinment, supra note 136, at 885 .

Recently, the Suprenie Court, in a 5-4 decision, applied a strict liability standard to municipahties in section 1983 damages actions in denying them a qualified inmunity based on the good faith of their officials. Owen v. City of Independence, $100 \mathrm{~S}$. Ct. 1398, 1409 (1980).

208. 604 F.2d 976 (5th Cir. 1979) (en banc), cert. denied, 100 S. Ct. 1339 (1980).

209. Id. at 978, 983. See, e.g., Guedry v. Ford, 431 F.2d 660 (5th Cir. 1970). See note 27 supra. 
against the private defendants as well. On appeal a Fifth Circuit panel upheld the doctrine, ${ }^{210}$ but in an en banc rehearing it overruled its long line of precedent and rejected derivative immunity for the private parties. 211

The majority opinion in the en banc Sparks decision began its analysis by recognizing that the scope of judicial immunity "should not be extended beyond that necessary to preserve the judge's independence of mind and judgment, for it is upon the manifest necessity to protect these, and on that alone, that the rule rests."212 Moreover, the court proceeded to declare "that no sound policy supports conferring any ... immunity on private persons who persuade a judge to exercise his jurisdiction corruptly."213 The court in Sparks did not specify the standard of liability it would apply to section 1983 private defendants. The language quoted above, however, indicates that the court approved a strict hability standard. Furthermore, in discussing the alleged conspiracy between the state judge and the private defendant, the court noted: "Sound policy suggests that atteinpts by [private] persons to subvert the judiciary slould be penalized in every just way, civil as well as criminal. It suggests that the fullest redress that the judicial system can accommodate while functioning effectively should be granted for such odious wrongs."'214

While the language of the statute indicates a strict liability standard, ${ }^{215}$ and although an arguinent for a good faith defense across the board for private persons is not particularly convincing, ${ }^{216}$ there are two instances in which something less than strict liability ought to be applied to private parties acting in concert with state officials. ${ }^{217}$ Those cases arise when private parties are simply obeying or are acting in

210. 588 F.2d 124, 126 (5th Cir. 1979) (per curiam).

211. 604 F.2d 976, 978, 983 (5th Cir. 1979) (en bauc), cert. denied, 100 S. Ct. 1339 (1980).

212. 604 F.2d at 980 .

213. Id. (emphasis added). In particular, the court rejected the policy argument that, without the derivative immunity doctrine, suits against private parties under section 1983 would result in time-consuming collateral attacks agamst immune state actors. See notes 118-28 supra and accompanymg text. "[T]he benefit that derivative immunity would accord in protecting judges from an obhgation to testify in the trial of their alleged co-conspirators, while not wholly illusory, is comparatively insignificant." 604 F.2d at 980 .

214. 604 F.2d at 980 .

In Norton v. Liddel, No. 78-1712, slip op. at 7-8 (10th Cir. Mar. 6, 1980), the Tenth Circuit also rejected the doctrine of derivative immunity. The court, lowever, did not indicate what standard of liability would apply to private defendants under section 1983, but merely held that when the elements of section 1983 (state action and a constitutional deprivation) are pleaded and proved, the statute may be einployed against the private defendant. Id. at 6-7.

215. See notes $32 \& 207$ supra and accompanying text.

216. See notes 219-20 infra and accompanying text.

217. See notes 226-32 infra and accompanying text. 
reliance on state officials. In these instances, a sense of fairness and public policy caution against adopting an inflexible rule that would hold private parties strictly liable for their acts. ${ }^{218}$

\section{An Alternative Approach}

This Comment has attempted to demonstrate that the doctrine of derivative immunity is unacceptable in evaluating the section 1983 liability of private persons who conspire with iminune state officials. The compromise solution of strict pleading suggested by the Court of Appeals for the Seventh Circuit is also unacceptable. Instead, the approach of the Courts of Appeals for the First and Fifth Circuits nore properly reflects the requirements of a valid section 1983 conspiracy claim. Accepting these pleading requirements as legitinate and assuming that a conspiracy can be proved, the problein that remains is whether persons should, in all instances, be strictly liable for their actions taken in concert with state officials, imunune or otherwise.

It has been suggested that private defendants in section 1983 actions should be given an across-the-board good faith defense. ${ }^{219}$ This proposal, however, anounts to extending a quahfled imınunity to private persons. Under the standards the Supreme Court has developed for extending section 1983 immunity, private persons, as a general rule, do not qualify. 220

This Comment proposes that a sliding scale of liability be developed for private persons who act in concert with public officials. Under this approach, private persons would be divided into three groups: those who act on equal footing with state officials, those who act in reliance on state officials, and those who act in obedience to state offcials. 221

218. See Downs v. Sawtelle, 574 F.2d at 16 (Coffin, C.J., dissenting).

The Tenth Circuit in Norton v. Liddel, No. 78-1712 (10th Cir. Mar. 6, 1980), recognized that all classes of private parties would not fall under the same standard of liability. Although the court did not expressly formulate this distinction, it specifically recognized a distimction between a private party who actively conspires with an immune official and a private party who works with and under an immune official. See id. ship op. at 14.

219. See "Vicarious Liability" 1038-39.

220. Nothing in the legislative history of section 1983 or the common law would permit the extention of qualified inmunity to private persons. In addition, private persons are not confronted with the pressures of office, so there is no policy rationale for extending immunity to them. For additional discussion, see notes 98-106 supra and accompanying text. Further, "Congress" failure to require proof that a section 1983 defendant has intentionally violated the Constitution is particularly strong evidence of its desire that such defendants should not be easily immunized." Schnapper 241.

221. The question whether a private party acted on equal footing with, in reliance on, or in obedience to a state official in every case should be determined by the factinder. The proposed variable scale would establish the standard for liability once this question of fact has been re- 
A strict liability standard should apply to private persons who conspire on equal terms with state officials. This is the standard of liability that applies to a state official absent any immunity defense and a literal reading of section 1983 would counmand this result. ${ }^{222}$ The holding of the Supreme Court in United States v. Price 223 illustrates this standard. In Price, the public and private defendants were engaged in a "joint activity" and the Court held that they "must suffer the consequences of that act." 224 The public defendants in Price inade no claim of immunity, but, as has been noted, 225 the liability of the private party should in no way be contingent on the fortuitous immunity of the public official.

A negligence standard, however, should apply wlien the private party has acted in reliance on a state official. In such a case, equity and fairness dictate that the private party be held to a lesser standard of liability-one closer to his standard of care in everyday life-even though he was engaged in a conspiracy witls the official. The negligence standard is generally articulated im terms of what a "reasonable person" would do in a similar situation. Nevertlieless, the standard involves four distinct considerations: the likelihood that the conduct would cause injury, the magnitude of the possible injury, the importance of the goal toward which the conduct was directed, and the availability of alternative methods of achieving that goal.226

The facts in Sparkman suggest a situation in which the negligence standard properly could be applied. ${ }^{227}$ Plaimtiff's mother approached a state judge and received his approval of a sterilization petition without any measure of due process. The private defendants in that case almost certainly would not have acted were it not for the state judge's signature on the sterilization petition. If in fact a conspiracy existed, the judge's immunity should not derivatively shield the private defendants. Instead, their liability should depend on the four considerations that comprise the negligence standard. Assuming that the plaintiff could have proven a conspiracy had she been allowed to proceed to discovery

solved. Because strict liability is the general rule under section 1983 , it is presumed that a defendant's claim of reliance or obedience would be an affirmative defense with the burden on the defendant to establish these facts at trial. The alternative would be to have the plaintiff allege and establish the absence of reliance or obedience as an element of his prima facie case. Clearly, establishing the existence of reliance or obedience is a less onerous burden for the defendant than is the burden of the plaintiff to establish their nonexistence.

222. See note 207 supra.

223. 383 U.S. 787 (1966). See notes 5-6 supra.

224. 383 U.S. at 795.

225. See note 146 supra and accompanying text.

226. W. Prosser, The LAW OF Torrs $\$ 31$, at $145-49$ (4th ed. 1971).

227. See notes 153-56 supra and accompanying text. 
and trial, it is not unreasonable to suggest that a jury might have found this negligence standard breached. ${ }^{228}$

The final category of private parties in section 1983 conspiracies is coinprised of those who act in obedience to an immune state official. In an obedience case, an official order (nost likely a judicial order) is imposed on a private party. Unlike the reliance situation, the private party has not approached the official seeking his assistance. For example, if the surgeons in Sparkman had been ordered by the court to sterilize the plaintiff, they would have been acting in obedience to, rather than in reliance on, the state judge. In this setting, a bona fide argument exists for extending immunity to the private party. ${ }^{229}$ The justification for a qualified immunity is twofold. First, the judicial, political, and administrative processes would be disrupted if those responsible for carrying out directives entertained doubts about the propriety of their acts. Second, subjecting to liability those who act pursuant to offcial orders while shielding those who issue the orders is manifestly unjust. 230

The immunity to be extended to the private defendant in obedience cases should be narrowly drawn. It may be argued that this imnunity should parallel the immunity of the state official issumg the orders. The better approach, however, would be to grant the private defendant a qualified immunity, determined by objective and subjective good faith. ${ }^{231}$ Otherwise, a successful section 1983 conspiracy be-

228. There was no doubt that the defendants' conduct would cause injury. Sterilization is a dramatic and grave mjury. See Skinner v. Oklahoma, 316 U.S. 535, 541 (1942) (procreation is fundamental and "one of the basic civil rights of man"). While the goal of preventing the plaintiff from becoming pregnant out of wedlock was arguably important, alternative methods of birth control are so numerous and common that the sterilization operation suggests lack of due care.

229. Merely extending the negligence standard to persons acting in obedience to public officials would be underinclusive. It is possible that a party who has acted in good faith may have also acted negligently. For example, in Jenkins v. Averett, 424 F.2d 1228, 1232 (4th Cir. 1970), the negligent shooting of a youth by a police officer was held actionable under section 1983 even though the shooting was unintentional. It should be noted that Jenkins was decided before the nature of the qualified imınunity test liad been defined in Scheter and Wood. See text accompanying notes 60-63 supra.

230. Developments in the Law 1199-200 n.68; see Sparkman v. McFarlin, 601 F.2d at 274 n.8 (Swygert, J., dissenting). Several courts have extended inmunity to court-appointed psychiatrists. See, e.g., Burkes v. Callion, 433 F.2d 318, 319 (9th Cir. 1970) (per curiain), cert. denied, 403 U.S. 908 (1971).

231. See notes 59-63 supra and accompanying text for a discussion of the good faith standard. Theoretically, in unany cases, extending qualified innunity to private defendants when they purportcdly lave acted in obedience to a state official would be irrelevant to the outcome of a section 1983 action. If the private defendant, in good faith, acted in obedience to a state official, the state action element would be absent, because a conspiracy could not be shown. The complaint, therefore, would fail to state a section 1983 claim against the private defendant and should be disnissed. This further illustrates the proposition that immunity for private parties under section 1983, as a general rule, is unnecessary. Extending a qualified immunity to the private defendant 
tween a judge and a private party framed in the context of a judicial order would leave both defendants absolutely immune to suit. A standard of objective and subjective good faith, however, would foreclose this not improbable scenario and at the same time shield the private party honestly acting in obedience to the court or another official.

Initially, this three-tiered standard may appear cumbersome. When attaching section 1983 liability to a private party alleged to have conspired with public officials, however, the law should consider all the circumstances im which the deprivation of the victim's rights took place. It is only in this fashion that proper account can be taken of the interests of all the parties. "Any mechanical approach to $\S 1983$ is flawed in that it is unresponsive to such considerations as they vary in the individual case, and the policy conscious $\S 1983$ court will eschew reliance on such rigid formulas." 232 The gross deficiences in the mechanical formulas of derivative immunity and strict pleading point to the obvious need for a variable standard of liability.

\section{CONCLUSION}

Application of derivative immunity to private persons who conspire with immune state officials to deprive another person of a constitutional right is not justifiable under section 1983. No court of appeals opinion adopting or applying the derivative immunity doctrine has provided a reasoned analysis to support its holding. A reading of the statute itself does not indicate any grant of immunity. More important, a careful analysis of the justifications advanced for the existimg governmental immunities demonstrates that they provide no rationale for extending immunity to private citizens. The policy arguments advanced by proponents of the derivative immunity doctrine are equally unpersuasive, amounting only to an after-the-fact attempt to preserve what has become a precedential rule of law.

In addition, the theory of derivative inmunity is itself analytically unsound. The courts that follow the doctrine have confused the issues of state action-a jurisdicitional predicate to a section 1983 cause of action-and the immunity of the state official-an affirmative defense. Furthermore, derivative immumity is a defense that attaches to a private party as a result of fortuity, rather than as a result of the individual acts of the private party. The strict pleading requirement suggested by the Court of Appeals for the Seventl Circuit in Sparkman is not a

in the obedience cases, however, would presumably alter the relative burdens of proving his $\mathrm{m}$ volvemeut in a conspiracy and more readily allow a showing of good faith to rebut circumstantial evidence of a conspiracy.

232. Bristow, supra note 124, at 319 . 
worthwhile compromise because it creates a needless conflict with the Federal Rules of Civil Procedure and suffers from many of the same defects as the derivative immunity doctrine.

Not surprisingly, when the doctrine has been carefully analyzed, it has been rejected. Recent decisions by the Courts of Appeals for the Fifth and Tenth Circuits and a consistent line of cases in the Court of Appeals for the First Circuit have refused to adopt derivative immunity. Instead, those courts have indicated that a private party who conspires with an immune public official to deprive another of a constitutional right should be strictly liable.

At a minimum, the proposed classification system for private parties in section 1983 actions lielps to unravel the confusion that has arisen in this area of section 1983 law. A private defendant who has acted on an equal basis witl a public official is certamly in a different posture than one who has acted in reliance on or im obedience to that official. A blanket rule cannot fairly cover all three situations.

Craig B. Merkle 